Research, part of a Special Feature on Adaptation in Fire-Prone Landscapes: Interactions of Policies, Management. Wildfire, and Social Networks in Oregon, USA

\title{
Diversity in forest management to reduce wildfire losses: implications for resilience
}

\author{
Susan Charnley $^{1}, \underline{\text { Thomas A. Spies }}^{1}, \underline{\text { Ana M. G. Barros }}^{2}$ Eric M. White $^{1}$ and Keith A. Olsen ${ }^{3}$
}

\begin{abstract}
This study investigates how federal, state, and private corporate forest owners in a fire-prone landscape of southcentral Oregon manage their forests to reduce wildfire hazard and loss to high-severity wildfire. We evaluate the implications of our findings for concepts of social-ecological resilience. Using interview data, we found a high degree of "response diversity" (variation in forest management decisions and behaviors to reduce wildfire losses) between and within actor groups. This response diversity contributed to heterogeneous forest conditions across the landscape and was driven mainly by forest management legacies, economics, and attitudes toward wildfire (fortress protection vs. living with fire). We then used an agent-based landscape model to evaluate trends in forest structure and fire metrics by ownership. Modeling results indicated that, in general, U.S. Forest Service management had the most favorable outcomes for forest resilience to wildfire, and private corporate management the least. However, some state and private corporate forest ownerships have the building blocks for developing fire-resilient forests. Heterogeneity in social-ecological systems is often thought to favor social-ecological resilience. We found that despite high social and ecological heterogeneity in our study area, most forest ownerships do not exhibit characteristics that make them resilient to high-severity fire currently or in the future under current management. Thus, simple theories about resilience based on heterogeneity must be informed by knowledge of the environmental and social conditions that comprise that heterogeneity. Our coupled human and natural systems (CHANS) approach enabled us to understand connections among the social, economic, and ecological components of a multiownership, fire-prone ecosystem, and to identify how social-ecological resilience to wildfire might improve through interventions to address key constraints in the system. Our methods underscore the importance of looking beyond the present to future trajectories of change to fully understand the implications of current natural resource management practices for adaptation and social-ecological resilience to natural disturbances.
\end{abstract}

Key Words: agent-based modeling; multiownership landscape; private corporate forestry; response diversity; state forestry; U.S. Forest Service

\section{INTRODUCTION}

"....it is only by encouraging and testing a diversity of approaches that we will be able to build landscapes that are resilient to future change." (Cumming et al. 2013:1139).

Better understanding of coupled human and natural systems (CHANS) can improve ecosystem management and promote human adaptation to environmental and social change (Berkes et al. 2003, Liu et al. 2007b, McConnell et al. 2011, Leslie et al. 2015). But to date, few researchers have applied a CHANS approach to the study of fire-prone forest ecosystems (Moritz et al. 2014, Spies et al. 2014). The wildfire problem in the western USA is well documented (e.g., Calkin et al. 2014, 2015, Moritz et al. 2014, North et al. 2015). In short, fuel-laden, fire-prone forests-an outcome of forest management policies of the 20th centurycoupled with rising human populations inhabiting the wildlandurban interface (WUI) have led to increasingly large and disastrous wildfires over the past two decades. A CHANS approach to understanding the problem of wildfire management in fire-prone forests may facilitate adaptation strategies and policy change across public and private lands to encourage coexistence of people and wildfire (Moritz et al. 2014). CHANS research can also help identify key variables that constrain the ability of actors to manage for resilience to disturbance and environmental change (Carpenter et al. 2001, Bennett et al. 2005), pointing to leverage points in the system for intervention (Meadows 1999).
The goal of this study is to investigate how different forest owners manage their forestlands to reduce losses to high-severity wildfire in a multiownership, fire-prone forest landscape and gain insight into how to enhance ecosystem resilience to wildfire. The research questions we address are: (1) How are different large landowners in the system managing their forestlands to reduce wildfire losses? (2) What are the social and ecological drivers of actors' forest and fire management behaviors? (3) What are the potential outcomes of current forest management on different ownerships for increasing future forest resilience to wildfire? We expected that diversity in forest and fire management among landowners in our study area (southcentral Oregon) would contribute to environmental heterogeneity, and in doing so, enhance forest resilience to high-severity wildfire. We also expected that diversity in forest and fire management among forest landowners would make possible comparative analysis to identify adaptive management strategies and barriers to adaptation, providing insights for how to increase ecosystem resilience to high-severity wildfire. Unlike most researchers who study the social dimensions of wildland fire in the USA, we do not focus on the WUI and on protecting homes and structures. Instead, we are concerned with wildlands (including forests managed primarily for timber production), where the management goals are to reduce the exposure to wildfire of values such as timber assets, biodiversity, cultural resources, water quality, wildlife habitat, and recreation opportunities. 
In the western USA, fire-prone landscapes often contain multiple land ownerships that intermix in a complex mosaic. Different landowners have different management goals and approaches and are influenced by different decision-making drivers, and their lands have different management histories, resulting in social and ecological heterogeneity (Spies et al. 2014). This heterogeneity may pose challenges for collectively managing natural resources and disturbances at landscape scales (areas of heterogeneous environments or ownerships that are at least 1000 ha in size, and typically much larger) - a critical scale for planning and management in fire-prone systems (Collins et al. 2010, Hessburg et al. 2015).

Nevertheless, heterogeneity also creates opportunities for learning. Several researchers posit that dry forest ecosystems are characterized by positive, maladaptive feedback loops in which efforts to reduce wildfire risk through fire suppression, insurance policies, and postfire government assistance programs exacerbate the wildfire problem (e.g., Calkin et al. 2015). They do this by creating more flammable conditions in forests (increasing the likelihood of high-severity wildfire), while making it safer for people to live in the WUI. Enabling population growth in the WUI increases potential exposure to wildfire, the cost of fire suppression to protect homes and property, and potential wildfire losses. However, ecosystem heterogeneity creates the possibility that diverse CHANS interactions and multiple feedbacks are at play, not all of which are maladaptive. Some researchers call for comparative studies of CHANS across geographic settings to gain insights for improving ecosystem management (Berkes and Folke 1998, Liu et al. 2007a). Others suggest management experiments that employ a variety of approaches to solving a natural resource management problem to identify which are best for increasing resilience (Cumming et al. 2013). In this study, we investigate what can be learned about social-ecological resilience to wildfire by examining diverse approaches to forest and fire management by different actors within a CHANS.

Of interest to some resilience theorists are the roles of "redundancy" and "response diversity" in fostering the resilience of CHANS to environmental change (e.g., Leslie and McCabe 2013, Mori et al. 2013, Kotschy et al. 2015). Maintaining redundancy and diversity is a key principle for building the resilience of social-ecological systems (Biggs et al. 2015). Redundancy occurs when elements within an ecosystem (i.e., different species, people, institutions) contribute to the same functional role. Redundancy increases resilience by ensuring that an ecosystem will keep functioning if some of its elements fail (Gunderson et al. 2002, Elmqvist et al. 2003, Low et al. 2003, Kotschy et al. 2015). In ecology, response diversity occurs when functionally redundant species respond differently to the same disturbance (Elmqvist et al. 2003). Ecosystems characterized by high response diversity contain a buffer against disturbances, making them more resilient (Elmqvist et al. 2003, Walker et al. 2006, Mori et al. 2013). People also vary in their responses to changing environmental circumstances; response diversity among people is defined by Leslie and McCabe (2013) as heterogeneity in human decisions and actions (e.g., natural resource use and management) that affects one or more of the same ecosystem functions. Forest owners in our study area may function as a redundant group because they all engage in forest management, provide overlapping ecosystem services (e.g., forest products, wildlife habitat), and they are all concerned with reducing the likelihood of large, severe wildfires. They exhibit response diversity in that their strategies for forest management and wildfire mitigation differ. The outcomes of response diversity among people for the resilience of social-ecological systems have been little studied (Leslie and McCabe 2013).

Our expectation that response diversity in forest and fire management by different landowners - past and presentcontributes to heterogeneous forest conditions is supported by the literature (Turner et al. 1996, Stanfield et al. 2002, Spies et al. 2007, Steen-Adams et al. 2015). The idea that heterogeneous forest characteristics may enhance forest resilience to highseverity wildfire is also supported by the literature (e.g., Finney 2001). In forest ecosystems, heterogeneous forest structure and composition can enhance resilience to disturbance by slowing the spread of disturbance agents such as fire - making them easier to manage - and by diversifying the effects of, and ecological responses to, disturbance. Management heterogeneity also supports greater biodiversity (Spies et al. 2007), which increases the capacity of biota to survive or recover from disturbance (Elmqvist et al. 2003, Norberg et al. 2008, Mori et al. 2013). In addition, heterogeneity in forest characteristics creates diverse conditions for the development of alternative ecological trajectories under uncertain future conditions, providing options for managers to spread risk (Moritz et al. 2014). Fuel conditions (e.g., surface fuels, height to live tree crowns, tree stand and crown density, and ability of trees to resist wildfire) are also key for influencing forest resilience to wildfire. Heterogeneity in fuel conditions as a result of management can affect the spread of fire across landscapes, but resilience to fire can be altered by fuel treatments or wildfires that reduce forest fuels.

From a social standpoint, forest and fire management diversity may enhance resilience to disturbance when different natural resource management institutions provide alternative approaches to solving the same problem. Diverse approaches make it possible to compare outcomes and learn how to improve governance to achieve desired objectives (Norberg et al. 2008). They also create options for adaptation in the face of future change (Norberg and Cumming 2008, Cumming et al. 2013, Kotschy et al. 2015).

Thus, in this article, we draw on empirical data about forest and wildfire management by large actors (federal, state, private corporate) in southcentral Oregon to investigate the relationship between response diversity, heterogeneity, and the resilience of a fire-prone forest ecosystem to high-severity wildfire. We evaluate ecosystem resilience using a suite of forest structure and highseverity wildfire potential metrics using an agent-based model (Spies et al. 2014, 2017). Many CHANS researchers have used agent-based models to model the diverse decisions and behaviors of individuals in the social system (Janssen 2002, An 2012), but they often develop them on the basis of assumptions about how individual actors behave rather than empirical data. Moreover, few studies examine the natural resource management decisions and behaviors of organizational (as opposed to individual) actors and how they are shaped by diverse institutions and social and ecological drivers (Rounsevell et al. 2012). Additionally, few agent-based models evaluate the outcomes of agent heterogeneity for spatial land use and management dynamics (Huang et al. 2014). Our study addresses these gaps. 


\section{METHODS}

\section{The study area}

The study area is located in the eastern Cascades region of southcentral Oregon and includes the forested portions of Klamath and Lake Counties, covering over 2.2 million ha, or $22,026 \mathrm{~km}^{2}$ (Fig. 1). This region forms the southern half of the "Forests-People-Fire" project area (Spies et al. 2014). The region has mountainous topography and environmental gradients that span wet, subalpine forests, moist and dry mixed-conifer forests, ponderosa (Pinus ponderosa) and lodgepole (Pinus contorta) pine forests, and semiarid juniper (Juniperus sp.) woodlands. Three frequent-fire forest types - moist mixed conifer, dry mixed conifer, and ponderosa pine-comprise the main potential vegetation types (PVTs) (Merschel et al. 2014, Stine et al. 2014).

Fig. 1. The study area in southcentral Oregon, with land ownership. Different shades of green represent different districts of the Fremont-Winema National Forest. Different shades of blue represent different private corporate ownerships.

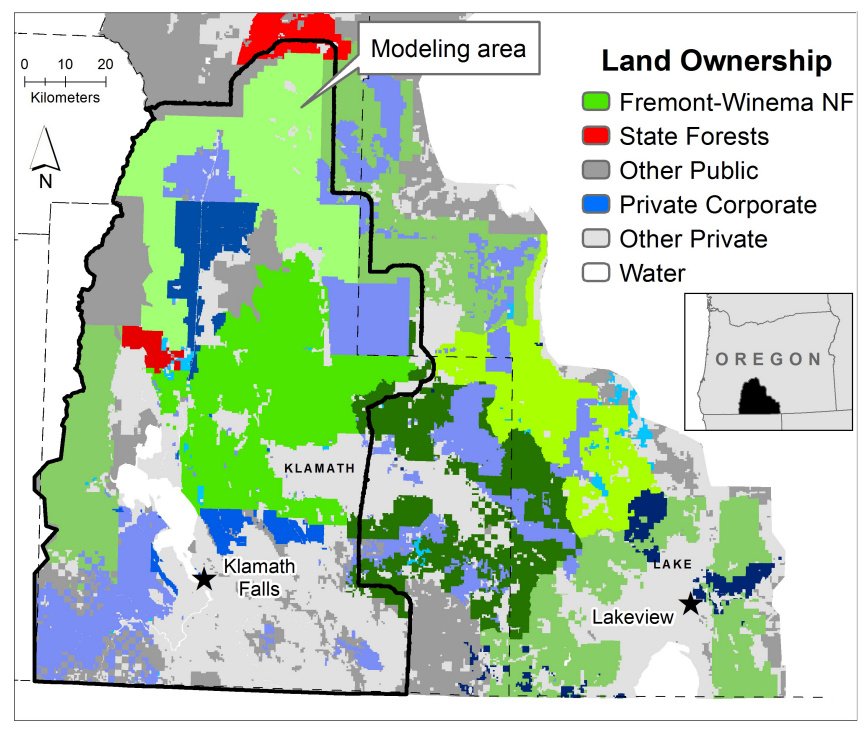

Land ownership is dominated $(1,000,203$ ha or $45 \%)$ by U.S. Forest Service (USFS) lands of the Fremont-Winema National Forest (FWNF), which is subdivided into seven ranger districts (it also includes a small portion of the Deschutes National Forest). The Oregon Department of Forestry (ODF) manages the Sun Pass State Forest and the Gilchrist State Forest (totaling 24,939 ha or $1.1 \%$ of the study area), and regulates forest management activities on private ownerships. There are also five private corporate forest owners owning 10,000 ha or more $(367,623$ ha total or $16.7 \%$ of the study area), referred to here as PC1-PC5 to protect privacy. All of these ownerships are intermixed (Fig. 1). Together, these large actors manage nearly two-thirds of the forested landscape in the region (Fig. 2), and are the focus of our analysis.

\section{Management of forests, fuels, and fire}

We used both qualitative and quantitative methods to examine how large actors were managing their forestlands to reduce wildfire losses, and the social and ecological drivers of these behaviors. This information was also used to model the behavior of large actors. Qualitative methods entailed conducting semistructured interviews with a purposive sample of organization representatives between March 2012 and July 2013. Forest Service employees interviewed $(n=41)$ were those who were directly engaged in planning or implementing fire or forest management activities, made decisions about these activities, or did work that informed them. State and private corporate forest interviewees were foresters who oversaw management on each of these ownerships ( $n=1$ per entity). Interview questions focused on management goals, land-use and ownership history, current landscape conditions, forest and fire management activities, decision-making drivers, and opportunities and constraints to meeting management goals. Interviews were recorded and transcribed, and the data entered into an Excel spreadsheet with topics organized by column and individual interviews organized by row. Data analysis occurred by synthesizing information in each column for each topic of interest. Other qualitative data sources included documents such as forest management plans (USFS and state), National Environmental Policy Act analysis and decision documents (USFS), and Forest Stewardship Council audit reports (two private corporate ownerships).

Fig. 2. Percentage of total study area owned by each actor group.

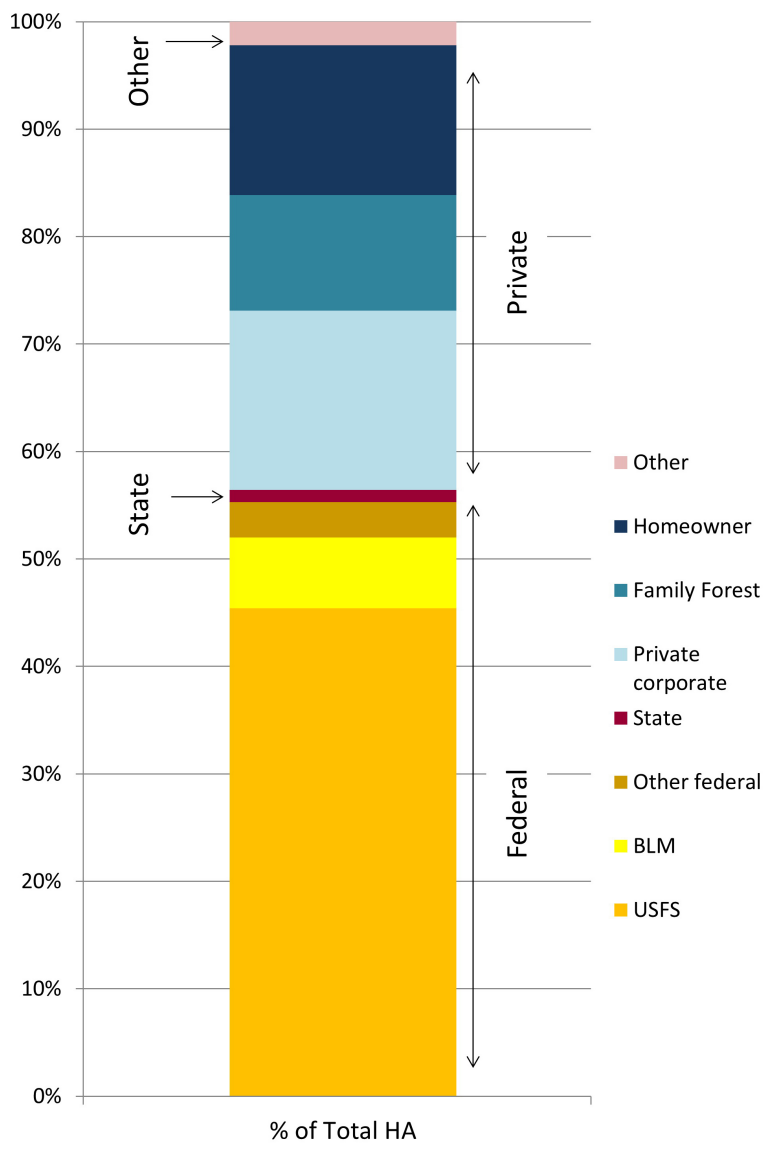


Quantitative data pertaining to forest and fire management were obtained from agency databases. For the FWNF, we examined fuel-treatment data from the Forest Service Activity Tracking System (FACTS) database for the years 2006-2013, and timber volume sold data from the Timber Information Manager System (TIMS) for the years 2006-2012. For private corporate owners, we examined notifications of operation filed with ODF prior to timber harvesting, as required by the Oregon Forest Practices Act. Notifications of operation include number of acres to be harvested, harvest methods, estimated board feet to be removed, and harvest location. We obtained notifications of operation for the years 2003 through 2013 for companies established prior to 2003, and through 2013 for companies established after 2003, starting with the year in which they acquired their forestlands.

\section{Current and projected future forest structure, wildfire, and timber harvest}

We used the agent-based model Envision, developed for central and southcentral Oregon, to evaluate the potential future forest structure and high-severity fire outcomes of current forest management practices (Spies et al. 2014, Barros et al. 2017). Envision models how actor behavior (through changes in vegetation and fuel conditions) interacts with vegetation succession and wildfire on individual landscape decision units (IDUs), ranging from 3 to 10 ha in size.

Vegetation change was modeled using state and transitions developed by USFS ecologists (Burscu et al. 2014). State and transition models were based on vegetation types defined according to cover, tree size, canopy layering, species, and PVT. The IDUs were assigned to a vegetation state and transitioned to other successional states according to deterministic or probabilistic successional transitions unless fire or management occurred in the IDU. The latter caused the vegetation to shift to a new structural state that depended on the severity of the disturbance (Spies et al. 2017). Management disturbances, which alter forest structure and fuel model states and transitions, were modeled in Envision based on information obtained from interviews and surveys of landowners (Spies et al. 2017).

Fuel models (i.e., fuel conditions sensu Scott and Burgan 2005) were assigned to vegetation states based on a fuel model layer from Landfire (Rollins 2009) (http://www.landfire.gov/viewer) and the Deschutes National Forest (Lauren Miller, personal communication) for a small portion of the study area that occurs there. Often, multiple fuel models occurred within each IDU/ vegetation state, in which case the majority fuel model was assigned to that state from the spatial data layers. Fuel models change with changing vegetation states and disturbances. For disturbances (e.g., surface fire) that affect surface fuels but not the vegetation state or canopy fuels, fuel model variants were developed based on expert opinion (see Barros et al. (2017) for a description of fuel models). A new fuel model was assigned after: (1) prescribed fire or surface wildfire, (2) mixed-severity fire, (3) high-severity fire, (4) mowing and grinding, or (5) timber harvest. The fuel model variant remains associated with the postdisturbance vegetation state for a set period of time, or until the vegetation state transitions to a new state.

Three actor groups were represented in our model: federal (USFS), private corporate, and state. Actors can modify forest vegetation by commercial timber harvests, tree thinning, mechanical surface fuel treatments, and prescribed fire, all of which can alter forest structure and fuel models (Appendix 1). For federal, state, and corporate ownerships, a timber volume or treatment area target approach was used. The target approach allows for implementation of actions (e.g., different types of fuel treatments or different types of harvests) that may be subject to a budget constraint or an implementation target.

Fires were simulated using the Envision fire module, which was parameterized based on historical spatiotemporal patterns of lightning and human ignitions and fire size for the last 20 years. Ignitions were sampled on the landscape, and fire growth and behavior were modeled as a function of fuels, topography, and a burn period and weather conditions specific to each ignition. Fire outputs for each year corresponded to fire perimeters and flame length (at the IDU level) within the simulated burned area and were based on the minimum travel time algorithm (Finney 2002) implemented in Envision through the Flammap dll. Any IDUs burned in one year were assigned a new surface and canopy fuels condition based on the preburn vegetation state and the simulated flame length. Besides simulation of fire perimeters, the fire submodel in Envision allowed for static fire behavior simulation under which a flame length was calculated for all IDUs using fixed weather conditions (Spies et al. 2017). High-severity fire potential areas were defined as areas where fire kills at least $80 \%$ of the basal area.

Although we describe large landowner management for the entire study area to provide a broad picture of actor diversity, we present the landscape model results for the western half of the study area only, where ownership is the most heterogeneous. The ownerships represented in the model results include three of the seven districts of the FWNF (Chemult, Chiloquin, and Klamath), the Sun Pass and Gilchrist State Forests, and four of the five private corporate ownerships (Table 1). Only 31\% of Gilchrist State Forest lands lie within our study area; results for this ownership may not apply to the entire state forest.

Table 1. Land ownership size, modeling area

\begin{tabular}{lcc}
\hline \hline Ownership & $\begin{array}{c}\text { Total ha, SW modeling } \\
\text { area }\end{array}$ & $\begin{array}{c}\text { Percentage of total SW } \\
\text { area }\end{array}$ \\
\hline Chemult District & 160,302 & $14.3 \%$ \\
Chiloquin District & 187,158 & $16.7 \%$ \\
Klamath District & 75,952 & $6.8 \%$ \\
Sun Pass State Forest & 8703 & $0.8 \%$ \\
Gilchrist State Forest & 5321 & $0.5 \%$ \\
PC1 & 140,054 & $12.5 \%$ \\
PC2 & 36,826 & $3.3 \%$ \\
PC3 & 18,944 & $1.7 \%$ \\
PC4 & 3692 & $0.3 \%$ \\
\hline
\end{tabular}

We characterized current forest structure using the Gradient Nearest Neighbor (GNN) method (Ohmann et al. 2011) based on 2008 imagery and inventory plots (Spies et al. 2017). Forest and vegetation structure were classified into seven size classes $(0 ;<12 \mathrm{~cm} ; 12-25 \mathrm{~cm} ; 25-37 \mathrm{~cm} ; 37-50 \mathrm{~cm} ; 50-75 \mathrm{~cm}$; and $>75$ $\mathrm{cm})$, four canopy cover classes $(<10 \% ; 10-40 \% ; 40-60 \% ;>60 \%)$, and two classes representing either single or multistoried stands. Land-ownership data were based on county tax lot data obtained from ODF.

We projected current management for 50 years using an annual time step and ran 15 simulations of Envision to account for 
stochastic variation in fire (Barros et al. 2017). We used six primary metrics to evaluate relative differences in forest structure, stand-replacing wildfire, and timber production across ownerships (Table 2). Metrics are reported as means with confidence intervals or distributions.

Table 2. Metrics used to evaluate relative differences in forest resilience to stand-replacing wildfire

\begin{tabular}{|c|c|c|}
\hline Forest structure & Wildfire & Timber harvest \\
\hline $\begin{array}{l}\text { Tree size: percentage of } \\
\text { ownership having trees } \\
\text { and other vegetation in } \\
\text { different size classes }\end{array}$ & $\begin{array}{l}\text { Potential fire hazard: } \\
\text { percentage of } \\
\text { ownership having the } \\
\text { potential for high- } \\
\text { severity (stand- } \\
\text { replacing) fire }\end{array}$ & $\begin{array}{l}\text { Timber harvest: volume } \\
\text { (cubic meters) of } \\
\text { merchantable timber } \\
\text { harvested }\end{array}$ \\
\hline $\begin{array}{l}\text { Canopy cover: } \\
\text { percentage of } \\
\text { ownership in different } \\
\text { forest canopy cover } \\
\text { categories (based on } \\
\text { trees }>25 \mathrm{~cm} \mathrm{dbh)} \\
\text { Ecological state: } \\
\text { percentage of } \\
\text { ownership exhibiting } \\
\text { early successional or } \\
\text { fire-resilient } \\
\text { characteristics }\end{array}$ & $\begin{array}{l}\text { Potential fire loss: } \\
\text { percentage of } \\
\text { ownership experiencing } \\
\text { high-severity (stand- } \\
\text { replacing) fire }\end{array}$ & \\
\hline \multicolumn{3}{|c|}{$\begin{array}{l}{ }^{\dagger} \text { Early successional characteristics included grass/shrub, seedling/sapling } \\
\text { vegetation with open and moderate forest cover, and poles } 12.7-25.4 \mathrm{~cm} \\
\text { dbh where the cover was }<10 \% \text {. Fire-resilient forests were defined as those } \\
\text { with large and giant trees in open and single-storey moderate forest canopy } \\
\text { conditions for fire-frequent potential vegetation types (moist mixed } \\
\text { conifer, dry mixed conifer, and ponderosa pine) in this region, based on } \\
\text { Merschel et al. } 2014 \text { and Hagmann et al. 2013). }\end{array}$} \\
\hline
\end{tabular}

Forest structure metrics describe the percentage of ownership in different canopy cover classes, tree size classes, and ecological states. Potential fire loss uses simulated fire perimeters and associated area burned to estimate projected fire losses as standreplacing fire. It reflects expected area burned by ownership type based on the historical pattern of natural and human ignitions and fire size. Potential fire hazard uses the output from the Flammap static run to calculate the overall percentage of the landscape with potential for stand-replacing fire under predefined weather conditions corresponding to the 90th percentile of days with burned area (see Spies et al. 2017). Timber harvest quantifies the projected timber harvest through time from each ownership.

To determine how different land ownerships and land management groups burned proportionally to their abundance on the landscape, we calculated fire incidence in ownership $o$ and land management group $m\left(\mathrm{I}_{\mathrm{om}}\right)$ as an adaptation of the Jacobs' selectivity index (Jacobs 1974). Typically, selectivity indices measure overuse of a resource compared with its abundance and, therefore, require the definition of "consumed" vs. "available" resources. In this work, we focus on how different ownerships burn with stand-replacing fire on the overall landscape and within management groups. We define "availability" as the proportion of area (PA) in management group $m$ that corresponds to landowner $o$ :

$$
P A_{o, m}=\frac{A_{o, m}}{A_{m}}
$$

and define "consumption" as the proportion of area burned (PB) in management group $m$ that corresponds to landowner $o$,

$$
P B_{o m}=\frac{A B_{o, m}}{A B_{m}}
$$

where $o$ represents landowners ( $o=\mathrm{FWNF}$, state, corporate) and $m$ represents management group (all lands, forested, fire prone); $\mathrm{AB}_{\mathrm{o}, \mathrm{m}}$ corresponds to area burned as stand-replacing fire in landowner $o$ and management group $m$, and $\mathrm{AB}_{\mathrm{m}}$ corresponds to total burned area (sum of all ownerships) as stand-replacing fire in management group $m$. $\mathrm{A}_{\mathrm{o}, \mathrm{m}}$ represents total area in ownership $o$ and management type $m$, and $\mathrm{A}_{\mathrm{m}}$ represents total area in management type $m$. The fire incidence index, $\mathrm{I}_{\text {om }}$, is calculated as Jacobs' selectivity index:

$$
I_{o m}=\frac{P B_{o, m}-P A_{o, m}}{P B_{o, m}+P A_{o, m}-2\left(P B_{o, m} P A_{o, m}\right)}
$$

\section{RESULTS}

Question 1: How are different large landowners in the system managing their forestlands to reduce wildfire losses?

Large actors in our study area exhibited a high degree of response diversity in their forest and wildfire management activities (Tables 3-5). This diversity was apparent among ownership categories (Forest Service, state, private corporate); within ownership categories (on different state forests and private corporate ownerships); and within individual ownerships (on different national forest districts, on different tracts within individual private corporate ownerships).

\section{Forest Service}

The priority forest management goals on the FWNF are (1) dry forest restoration to reduce fuel loads, improve wildlife habitat, maintain late-successional and old-growth habitat and big trees, and restore riparian areas; (2) to produce forest products to keep mills in operation and support local jobs; and (3) to honor the rights and obligations associated with managing the Klamath Tribes' former reservation lands that are now part of the FWNF. A key objective of dry forest restoration is to restore forest conditions so that wildfire can play a more natural role in the ecosystem and provide ecological benefits.

Forest management for fire hazard reduction is accomplished using mechanical treatments (e.g., thinning, mastication, mowing, lopping, and scattering), prescribed fire, and piling and burning of slash. The goals of forest management and associated management actions vary somewhat across the seven districts of the FWNF (Table 3) owing to different social and ecological conditions associated with each district. Many USFS interviewees believed the most effective treatments were mechanical treatments followed by prescribed fire. The specific mix of mechanical treatments and prescribed fire, as well as the total magnitude of area treated, differ across the districts (Fig. 3). In all cases, following national direction, the WUI is a high priority for fuels reduction on the FWNF. Hazardous fuels reduction and timber production are often accomplished in the same project, allowing timber and fuels objectives to be met simultaneously. Currently, the FWNF suppresses all wildfires that ignite there. 
Table 3. Forest management, Fremont-Winema National Forest Districts

\begin{tabular}{|c|c|c|}
\hline District & Management goals & Management activities \\
\hline Chemult & $\begin{array}{l}\text { Hazardous fuel } \\
\text { reduction, wildlife } \\
\text { habitat restoration, } \\
\text { timber production }\end{array}$ & $\begin{array}{l}\text { Nearly all harvest activity is thinning from below of trees between } 17.8 \mathrm{~cm} \text { and } 53.3 \mathrm{~cm} \text { dbh. Treatments focus on } \\
\text { high-density stands having big ponderosa pine trees and include removal of lodgepole pine and white fir where } \\
\text { they encroach on ponderosa stands. Also, remove conifers encroaching into hardwood habitats, i.e., aspen, and } \\
\text { meadows. WUI is a priority for treatments; also treat around riparian areas and in matrix and late-successional } \\
\text { reserves in the Northwest Forest Plan area. }\end{array}$ \\
\hline Chiloquin & $\begin{array}{l}\text { Hazardous fuel } \\
\text { reduction, timber } \\
\text { production, forest } \\
\text { health improvement }\end{array}$ & $\begin{array}{l}\text { Harvest by thinning from below. Priority treatment areas are places where old-growth ponderosa pine needs } \\
\text { protection, and WUI and adjacent areas. Main species removed are ponderosa and lodgepole pine and some white } \\
\text { fir, in the } 38.1 \mathrm{~cm} \text { dbh range but with an upper limit of } 53.3 \mathrm{~cm} \text {, except for } 76.2 \mathrm{~cm} \text { for white fir. Remove lodgepole } \\
\text { that encroaches into riparian areas having hardwoods. Another priority is to restore aspen stands. Some treatments } \\
\text { occur in Northwest Forest Plan area. }\end{array}$ \\
\hline Klamath & $\begin{array}{l}\text { Wildlife habitat } \\
\text { protection, recreation }\end{array}$ & $\begin{array}{l}\text { Harvest by thinning from below. Priority is treating old ponderosa pine stands by removing encroaching white fir } \\
\text { and lodgepole pine. Ponderosa pine and Douglas-fir are the target species for leaving behind after treatments. } \\
\text { District is within Northwest Forest Plan area; harvest trees up to } 53.3 \mathrm{~cm} \text { dbh in Late Successional Reserves and } \\
76.2 \mathrm{~cm} \text { in matrix. Also prioritize treating nesting habitat for bald eagles and northern spotted owls. Most } \\
\text { treatments occur in or near WUI. }\end{array}$ \\
\hline Bly & $\begin{array}{l}\text { Timber production, } \\
\text { hazardous fuel } \\
\text { reduction }\end{array}$ & $\begin{array}{l}\text { Priority is to restore ponderosa pine forests. Harvest white fir, lodgepole pine, and some ponderosa pine. Method } \\
\text { used is thinning from below. Conduct thinning to remove juniper. Average size of tree harvested on timber sales is } \\
27.9-30.5 \mathrm{~cm} \text { dbh. Harvest by thinning from below. }\end{array}$ \\
\hline Lakeview & $\begin{array}{l}\text { Timber production, } \\
\text { hazardous fuel } \\
\text { reduction }\end{array}$ & $\begin{array}{l}\text { Harvest by thinning from below. District is inside Sustained Yield Unit and provides most of the timber target for } \\
\text { the unit. Priority is removal of white fir from ponderosa pine stands; ponderosa and lodgepole also harvested. } \\
\text { Juniper is removed and burned. Most trees harvested are in the } 22.9 \mathrm{~cm} \text { to } 53.3 \mathrm{~cm} \text { dbh range. Conduct harvests on } \\
\text { rotations, watershed by watershed, over } 20 \text { - to } 30 \text {-year period. }\end{array}$ \\
\hline Paisley & $\begin{array}{l}\text { Timber production, } \\
\text { hazardous fuel } \\
\text { reduction, habitat } \\
\text { improvement }\end{array}$ & $\begin{array}{l}\text { Harvest by thinning from below. Harvest concentrated in portion of district that lies within Sustained Yield Unit } \\
(61 \% \text { of total district area). Restoration of ponderosa pine stands a priority. Trees harvested are } 17.8 \mathrm{~cm} \text { to } 53.3 \\
\mathrm{cm} \text { dbh, the majority being } 30.5-40.6 \mathrm{~cm} \text { dbh. Ponderosa, lodgepole, and white fir are harvested. }\end{array}$ \\
\hline $\begin{array}{l}\text { Silver } \\
\text { Lake }\end{array}$ & $\begin{array}{l}\text { Timber production, } \\
\text { forest restoration }\end{array}$ & $\begin{array}{l}\text { Harvest by thinning from below, mostly ponderosa pine and white fir. Priority is to restore ponderosa pine stands. } \\
\text { Also conduct juniper removal. Most trees removed are } 30.5-40.6 \mathrm{~cm} \text { dbh. A major fire in } 2002 \text { led to several years } \\
\text { of subsequent salvage harvest. }\end{array}$ \\
\hline
\end{tabular}

Fig. 3. Hazardous fuel reduction methods and activity on the Fremont-Winema National Forest, by district, fiscal years 2006-2013.

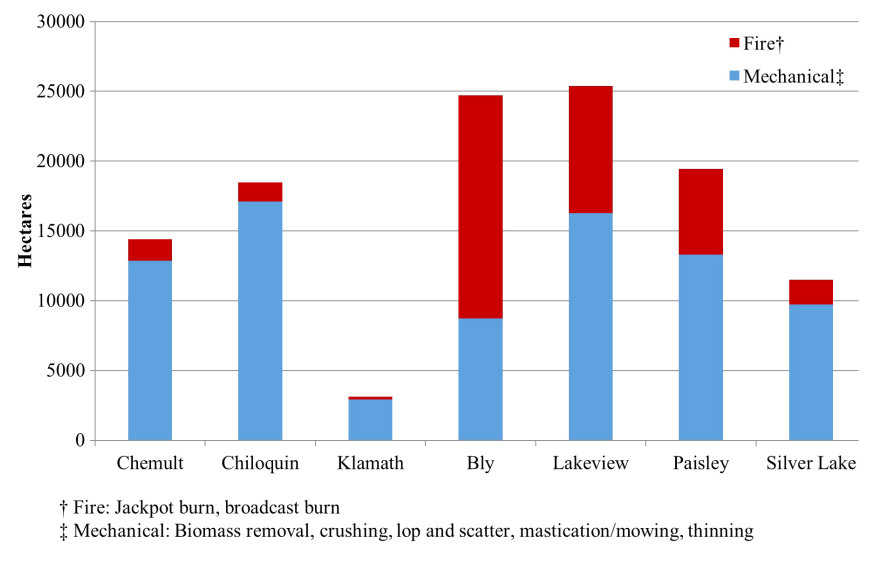

\section{State management}

The management goal on the Sun Pass and Gilchrist State Forests is to create a healthy, diverse forest and a sustained yield of timber products to generate revenue for local county governments, schools, and the Oregon Department of Forestry to help fund its operations. State forest budgets come from timber revenue. Forest management on the two state forests is quite different (Table 4), despite sharing the same management plan.
The ODF aims to reduce wildfire hazard on state forest lands as an outcome of the forest management actions described in Table 4. Harvests sometimes occur in checkerboard patterns to break up fuels. Supplementary actions taken to reduce wildfire hazard include burning slash piles following timber harvests and creating fuel breaks along roads. To reduce the chance of fire burning onto state forest lands, ODF conducts more intensive management along borders with federal lands - perceived as overstocked and posing a high likelihood of wildfire. The agency practices full wildfire suppression on its lands. If external grant funding is available, or markets for chips or biomass exist that offset treatment costs, then mechanical fuel reduction is carried out to remove overstocked, small-diameter trees through thinning and mastication. All treatments are mechanical; prescribed burning is not employed as a management tool.

\section{Private corporate management}

Private corporate forest owners vary in how they manage their lands (Table 5). All share the same management objective: to produce revenue through commercial timber production. However, each takes a different approach to achieving this goal, following different logics about current and future revenue streams. PC1 aimed to produce a fixed amount of revenue for its owners in order to meet debt obligations and provide a specified profit margin; thus, harvest levels fluctuate with market prices. PC3 purchased lands that had been lightly managed in the past and contained a large component of big trees, but adopted a strategy of liquidating valuable timber over the short term for fear that local wood-processing infrastructure (representing the 
Table 4. Forest management, State forests

\begin{tabular}{|c|c|c|}
\hline & Sun Pass State Forest & Gilchrist State Forest \\
\hline Management goal & $\begin{array}{l}\text { Create a healthy, diverse forest and produce a sustained yield of timber } \\
\text { products to generate revenue for counties, schools, agency. Promote } \\
\text { ponderosa pine forest. }\end{array}$ & $\begin{array}{l}\text { Reduce risk of fire, insects, and disease and grow } \\
\text { the forest for future value (stand improvement); } \\
\text { encourage ponderosa pine forest. }\end{array}$ \\
\hline Management activities & $\begin{array}{l}\text { Management became active ca. } 1995 \text {. } \\
\text { Uneven-aged management of heavily stocked trees to improve forest } \\
\text { health and produce timber, reduce fire risk through selection cuts: } \\
\text { thinning, overstorey removal of big trees infested with mistletoe, } \\
\text { species selection (e.g., priority to remove white fir). Manage on an } \\
\text { acreage target basis: } 485.6 \mathrm{ha} / \mathrm{year} \text {, reentering stands every } 20-30 \text { years. } \\
\text { First entry: remove undesirable spp., unhealthy trees in overstocked } \\
\text { stands; harvest } 10-12 \mathrm{mmbf} / \mathrm{yr} \text {. } \\
\text { Second entry: group selection cuts of } 0.2 \text { to } 2 \text { ha, all merchantable } \\
\text { wood; harvest } 6-8 \mathrm{mmbf} / \mathrm{yr} \text {. Revenue increases because now cut fewer } \\
\text { but bigger and more valuable trees at lower cost. } \\
\text { Plant ponderosa. } \\
\text { Harvest < growth. } \\
\text { Cut down to } 9.3-13 \mathrm{~m}^{2} \text { basal area. } \\
\text { Clearcut lodgepole in } 8.1-\text { to } 20.2 \text {-ha blocks on } 80 \text {-year rotation. }\end{array}$ & $\begin{array}{l}\text { Management began in } 2011 \text {. } \\
\text { Thin small-diameter trees in priority areas through } \\
\text { precommercial thinning. } \\
\text { Mastication. } \\
\text { No harvest of merchantable wood except removal } \\
\text { of unhealthy lodgepole left as seed trees. } \\
\text { Leave ponderosa pine to encourage recovery. } \\
\text { Let trees grow so they can be merchantable in the } \\
\text { future. } \\
\text { Aim to treat } 1214-1618 \text { ha/year. }\end{array}$ \\
\hline
\end{tabular}

market) would decline, rendering its timber assets worthless. PC2 managed forests on land that was for sale for forest use or development during the study period and was, therefore, protecting the value of its property investment by focusing on stand improvement, as the land had been heavily cut over by the previous owner. However, one large tract, previously part of the Klamath Tribal Reservation, was managed to produce a sustained yield of wood products consistent with the Klamath Termination Act (Appendix 2). PC5 managed to produce a sustained yield of high-quality timber products over the long term. PC4 managed for sustained yield timber production as well as stand improvement and forest health protection. Private corporate owners often manage individual tracts within their ownerships differently, depending on forest conditions (e.g., old plantations vs. natural stands).

Management to reduce wildfire losses is viewed as an outcome of mechanical harvesting, which generally is designed to create stands with high spacing between trees, open canopies, and low basal area in order to increase growth rates through reduced competition and reduce the perceived chance of tree mortality during wildfire. All private corporate owners practice full fire suppression. No private corporate owners use prescribed burning to treat surface fuels. Other wildfire mitigation actions include burning slash piles, understory thinning of submerchantable material when it can be sold as chips, and more intensive management along borders with federal lands, which are viewed as posing a high wildfire threat, including creation of shaded fuel breaks (areas with very low basal area and limited undergrowth).

\section{Question 2: What are the social and ecological drivers of actors' forest and fire management behaviors?}

The interviews indicated that key drivers of forest and fire management behavior were: (1) forest management legacies, specifically structure and composition of vegetation as a product of past management and fire; (2) market conditions for wood products and desired revenue streams; and (3) attitudes toward fire, characterized here as "fortress protection" versus "living with fire." These drivers are interrelated, although they are not the only drivers of management behavior (see for example Charnley et al. 2015 for USFS lands).

\section{Forest management legacies}

The forest ownerships in our study area have diverse management histories (Appendix 2). Management history shapes the forest; "landscapes have memory" (Foster et al. 2003). Different tree species, size classes, and densities - in part a product of past management - call for different treatments. The important role of landscape legacies is illustrated by the two state forests, which exhibit contrasting forest structures. Sun Pass has a high percentage of closed canopy cover and big trees, whereas Gilchrist is dominated by small trees and lower canopy cover. Sun Pass was acquired in the 1940s and only lightly managed until the 1990s, during which time the trees had grown in size following heavy harvest by the previous owner. Gilchrist was heavily cut over in the 1990s by a previous owner who went bankrupt. The land was then acquired by a real estate investment trust and put up for sale. The state purchased what is now the Gilchrist State Forest in 2010 to protect open space, public access, and working forestlands and to prevent its conversion to real estate development. These legacies strongly affect current management of the two state forests, which differs despite having the same management goals and management plan.

\section{Markets and desired revenue}

The three large actor groups operate under very different financial constraints. Federal land management is partially supported through Congressional appropriations, which pay for a large share of wildfire mitigation on federal lands. For example, the FWNF receives funding to achieve a fuel reduction target of about 8100 ha annually. Fuel reduction treatments are also funded through stewardship contracts, where typically, the value of harvested timber is used to pay for other noncommercial restoration activities, such as precommercial thinning or road improvements. Although Congressional appropriations may be insufficient, tools (e.g., stewardship contracts) and external sources of funding (e. g., Resource Advisory Committees, NGO partners) may be available to help meet the target. In contrast, state forest funding 
Table 5. Forest management, private corporate ownerships

\begin{tabular}{llll}
\hline \hline PC1 & PC2 & PC3 & PC4 \\
\hline $\begin{array}{l}\text { Management goal } \\
\begin{array}{l}\text { Commercial timber } \\
\text { production to produce a } \\
\text { fixed amount of revenue }\end{array}\end{array}$ & $\begin{array}{l}\text { Produce sustained yield of } \\
\text { wood products, stand } \\
\text { improvement }\end{array}$ & $\begin{array}{l}\text { Short-term liquidation of } \\
\text { valuable timber and } \\
\text { growing more stock }\end{array}$ & $\begin{array}{l}\text { Sustained yield timber } \\
\text { production, stand } \\
\text { improvement, forest health } \\
\text { protection }\end{array}$
\end{tabular}

Management activities

Half of ownership in old plantations managed for fiber; half in natural stands managed for logs.

In plantations: first entry, take trees down from 300 350 per 0.4 ha to $150-180$; $10-15$ years later, thin again down to 80 trees per 0.4 ha. Aim for 10-12 tons of chips/ 0.4 ha. Harvest < growth. Natural stands: uneven-aged management, harvest trees $25.4-50.8 \mathrm{~cm}$ $\mathrm{dbh}$ for $6.1 \mathrm{~m}$ spacing. Harvest $\leq$ growth. Treat heavily along USFS border and create sheltered fuel breaks. Widen road corridors and clear dead trees.
Selectively thin ponderosa Uneven-aged management stands. Overstorey removal with spacing to open up plus thinning for chips in lodgepole stands, where most harvest occurs. Reentry after 20 years, 75 year rotation.

Thin areas along USFS

boundaries. Do understorey removal by thinning smalldiameter material for chip market. Thin to $4.6-6.1 \mathrm{~m}$ spacing. 20-year rotation for reentry. Harvest trees $15.2 \mathrm{~cm}$ to $53.3 \mathrm{~cm} \mathrm{dbh}$. Must meet harvest volume target of $8.3 \mathrm{mmbf} / \mathrm{year}$. Burn slash piles. stand and canopy. Harvest trees $25.4-76.2 \mathrm{~cm} \mathrm{dbh}$ Harvest as many hectares annually as possible $(2023+)$ out of 16,187 ha of timberland, harvest ca. 2000 board feet/ 0.4 ha. Produce logs and small volume of chips. Harvest > growth.
Uneven-aged management, Harvest trees $30.5-50.8 \mathrm{~cm}$ mostly thinning. Produce $4-$ dbh through thinning, $5 \mathrm{mmbf} / \mathrm{yr}$, can be variable encourage growth of bigger hectarages; harvest $<\quad$ trees. Heavy removal of growth. Reenter stands on white fir to open up stands. 5- to 10-year rotations. Remove some smaller Harvest trees $20.3-101.6 \mathrm{~cm}$ material for chips. Mixture $\mathrm{dbh}$. Aim for $8.4-11.2 \mathrm{~m}^{2}$ of of uneven-aged management basal area following harvest. Produce wood products for lumber, plywood, and chips. Create tree spacing to reduce fire risk. Treat more heavily for $137.2-182.9 \mathrm{~m}$ into their property along USFS borders to reduce risk of fire transmission. and individual and group selection cuts. Aim for evenly spaced, open stands of ponderosa pine with minimal ladder fuels. Produce 11-12 $\mathrm{mmbf}$ annually. Manage to $4.2-8.4 \mathrm{~m}^{2}$ of basal area. Reenter stands every 20-25 years. Burn slash piles. Harvest $=$ growth . can be traced to timber sale revenues, which are split with counties and state funds for schools. Funds are generally lacking to pay for removal of hazardous fuels that have no commercial value unless external support is available (e.g., grants). Thus, little management activity occurs on the Gilchrist State Forest, dominated by small trees that lack commercial value. Private corporate owners face the greatest financial constraints on fuel reduction. They pay property taxes, including an acreage assessment for fire protection by the state (unlike public actors), and carry insurance against loss to wildfire. Management activity is expected to generate revenue for owners and investors. Unlike family forest owners, only a limited number of grant or cost-share programs are available to private corporate owners to help them reduce wildfire hazard on their properties. Consequently, as one private corporate interviewee stated:

As far as private ground, it is the issue of how do you economically reduce the basal area and thin, just thin?... You can thin, but if you lay it on the ground, you got a big problem... how do you pay to drop it, and how do you deal with it? ... We have been doing some more chipping ... but it's a long ways from the market, and it is expensive to do that.... If the stands ... pretty well all need thinning, then it's a straight-up financial investment in the ground to do that. That's tough to do in today's market ....

\section{Attitudes toward fire}

Landowners have a variety of attitudes toward fire. State and private corporate actors adopt fortress protection to exclude fire and protect timber assets (Fig. 4), as they have historically. Private
Fig. 4. Fortress protection vs. living with wildfire.

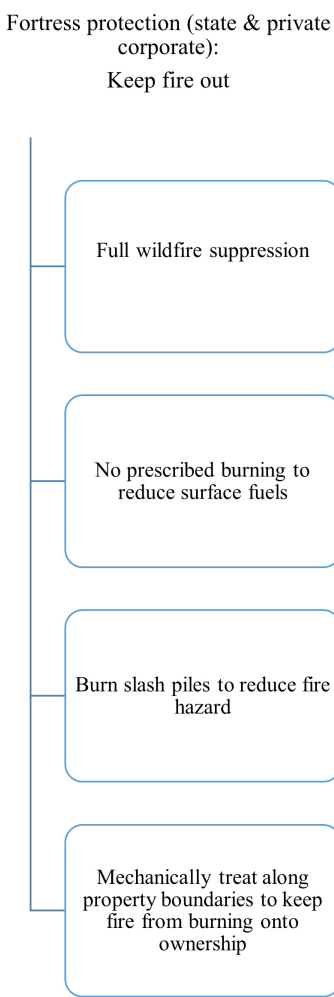

Living with fire (Forest Service): Reduce damage and increase ecological benefits from fire

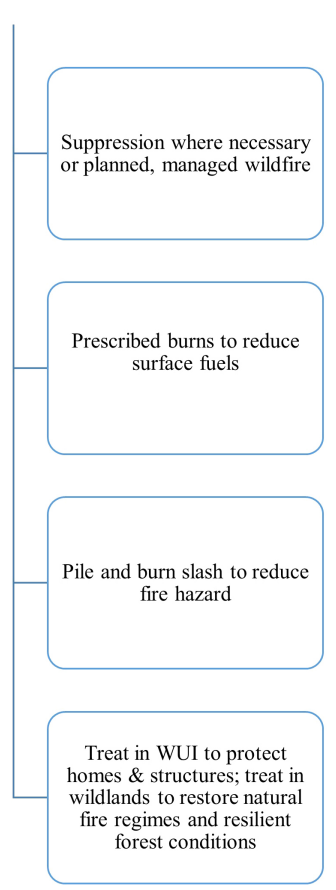


Table 6. Current forest structure conditions by ownership

\begin{tabular}{|c|c|c|c|c|c|c|}
\hline \multirow[t]{2}{*}{ Ownership } & \multicolumn{3}{|c|}{ Canopy cover class $(\%)^{\dagger}$} & \multicolumn{3}{|c|}{ Tree size class $(\mathrm{dbh}, \mathrm{cm})(\%)$} \\
\hline & $10-40$ & $40-60$ & $>60$ & $\begin{array}{c}<38 \\
\text { (small) } \\
\end{array}$ & 38-50 (medium) & $\begin{array}{c}>50 \\
\text { (large and giant) }\end{array}$ \\
\hline All Forest Service & 5.7 & 31.1 & 45.5 & 45.5 & 17.0 & 37.5 \\
\hline All State & 7.6 & 13.6 & 60.1 & 50.6 & 20.7 & 28.7 \\
\hline All Corporate & 16.8 & 20.2 & 33.0 & 66.5 & 20.4 & 13.1 \\
\hline \multicolumn{7}{|l|}{ Forest Service RD } \\
\hline Chemult & 2.3 & 22.8 & 44.6 & 68.2 & 9.7 & 22.0 \\
\hline Chiloquin & 10.3 & 32.1 & 45.5 & 36.2 & 23.2 & 40.7 \\
\hline Klamath & 2.2 & 51.4 & 45.1 & 11.1 & 16.9 & 72.0 \\
\hline \multicolumn{7}{|l|}{ State forests } \\
\hline Sun Pass & 8.2 & 10.6 & 74.3 & 31.7 & 26.6 & 41.7 \\
\hline Gilchrist & 2.3 & 17.7 & 32.0 & 86.4 & 7.1 & 6.5 \\
\hline \multicolumn{7}{|l|}{ Corporate owners } \\
\hline $\mathrm{PCl}$ & 19.8 & 22.0 & 26.0 & 64.3 & 24.0 & 11.7 \\
\hline $\mathrm{PC} 2$ & 4.5 & 18.7 & 48.0 & 94.4 & 1.0 & 4.6 \\
\hline PC3 & 18.4 & 9.4 & 50.7 & 33.5 & 31.2 & 35.3 \\
\hline PC4 & 12.1 & 13.4 & 69.3 & 28.6 & 26.5 & 44.9 \\
\hline
\end{tabular}

${ }^{\dagger}$ Results are for forested areas having trees $>25.4 \mathrm{~cm}$ dbh only, thus percentages do not add up to 100 .

corporate and state forest managers gave a number of reasons for not using prescribed fire, considered to be the most effective way to reduce the likelihood of high-severity fire in combination with mechanical treatments (Stephens et al. 2012). They believe they can reduce the occurrence of crown fire through timber harvest practices that space trees well, and by reentering stands on short rotations to remove hazardous material. Tree stress after prescribed fire can lead to insect (bark beetle) outbreaks (Fettig et al. 2007) (although they tend to be short lived and concentrated on smaller diameter trees (Stephens et al. 2012)). Prescribed fire can also promote rapid regrowth of shrubs that can compete for resources with new tree seedlings. Unlike mechanical treatments that enable them to control treatment outcomes, prescribed burning is not an easily controlled management tool. Private corporate owners may be liable for prescribed fires that escape from their properties and burn onto other ownerships, and escaped fires also threaten their timber stands. Private corporate owners also lack the person power needed to implement prescribed burns and monitor postburn conditions to ensure that no remaining embers flare. Smoke from prescribed fires can be controversial. Finally, prescribed burning costs money to implement and does not generate revenue.

Forest Service managers, in contrast, are more willing to live with fire as reflected by the FWNF's goal to restore fire as a natural part of the ecosystem (Fig. 4). Federal policy allows for managing rather than suppressing wildfire, as appropriate (North et al. 2015), although the FWNF still practices full fire suppression. Nevertheless, $31 \%$ of the area treated for fire hazard reduction on the FWNF between 2006 and 2013 used prescribed fire. (This calculation represents the percentage of acres treated by "broadcast burn" or "jackpot burn" of the total number of acres treated using jackpot burn, broadcast burn, biomass removal, crushing, lop and scatter, mastication/mowing, and thinning).

Question 3: What are the potential outcomes of current forest management on different ownerships for increasing future forest resilience to wildfire?
Current forest structure and potential wildfire hazard

Current forest structure and potential wildfire hazard varied widely both between and within land ownership categories. Private corporate lands had more than three times the percentage area of open canopy forest as FWNF lands and about twice the percentage of open canopy as state forests (Table 6). State forests had the highest amount of closed canopy forest as a percentage of their ownership, and private corporate the lowest. Within ownerships, variation in percentage open and closed canopy cover was very high among the private corporate and state owners, reflecting differences in management history and environment.

The highest percentage of large and giant trees occurred on FWNF lands, which had almost three times as much of this cover type as a percentage of its ownership as the private corporate lands (Table 6). The Klamath Ranger District had the greatest percentage $(72 \%)$ of all individual ownerships in large and giant trees, reflecting its management history and wetter forest environment conducive to faster growth. Not surprisingly, private corporate lands had the largest percentage of early successional and small trees (Tables 6 and 7). As with canopy cover, variation in percentage of different size classes of trees varied widely within ownership categories. Variation in percentage of size classes of trees on state forest lands covered the full range from very little area of larger trees and high amounts of young vegetation (Gilchrist) to the complete opposite (Sun Pass).

The amount of fire-resilient older forest structure in fire-prone vegetation types was very low on all ownerships, but generally twice as high on FWNF lands as on the other ownerships. This finding was primarily a result of the high percentage on the Chiloquin Ranger District, which had 13\% cover of open forests with larger trees (Table 7). The private corporate ownership with the highest amount of fire-resilient forest structure was PC3 (15\%) owing to its management history. 
Fig. 5. Change in forest structure characteristics between model simulation years 1 and 50, between and within forest ownership categories.
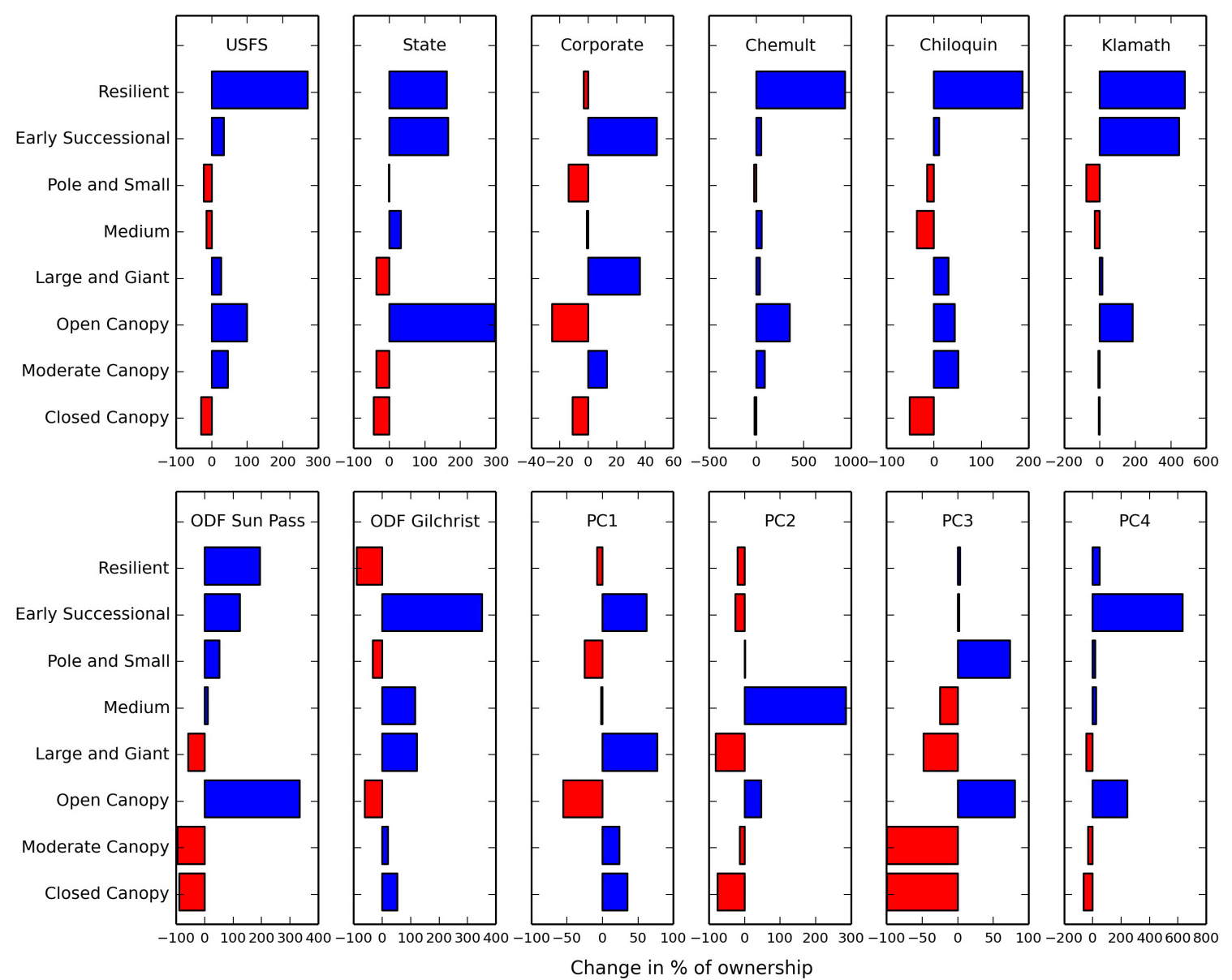

Table 7. Current ecological states by ownership

\begin{tabular}{lcc}
\hline \hline Ownership & $\begin{array}{c}\text { Early successional } \\
\text { vegetation, } \\
\text { \% of forested area }\end{array}$ & $\begin{array}{c}\text { Resilient forest } \\
\text { structure, } \\
\text { \% of frequent-fire } \\
\text { PVTs }\end{array}$ \\
\hline All Forest Service & 3.5 & 8 \\
All State & 2 & 4 \\
All Corporate & 8 & 4 \\
Forest Service RD & 3 & 2 \\
Chemult & 5.5 & 13 \\
Chiloquin & .5 & 2 \\
Klamath & & \\
State forests & 2.5 & 4.5 \\
Sun Pass & .5 & .5 \\
Gilchrist & & 3 \\
Corporate owners & 8 & 1 \\
PC1 & 3 & 14.5 \\
PC2 & 15 & 3 \\
PC3 & 1 & \\
PC4 & &
\end{tabular}

At the start of our model run (year 1, representing results after 1 year of simulated wildfires and management), potential fire hazard was highest overall on state and private corporate lands (Table 8). On private corporate lands, this finding was largely a function of smaller trees (lower height to crown base), more open conditions (e.g., less likelihood of crown fire but more understory wind), and higher fire spread flame length postharvest fuel models than on FWNF lands. On the FWNF, harvest was typically followed by surface fuel treatments (prescribed fire or mastication) that resulted in fuel conditions with very low rates of spread and flame lengths. The Klamath Ranger District had the lowest potential fire hazard (Table 8), likely because it occurs in relatively wetter environments than the other ownerships and because of a relatively low proportion of frequent-fire PVTs $(33.8 \%)$.

\section{Projected future forest structure, wildfire, and timber harvest} under current management

Projected changes in forest structure varied among and within the main ownership categories (Fig. 5). The largest relative changes occurred as the percentage of resilient forest vegetation increased substantially on FWNF and state lands (Sun Pass) in association with thinning and partial harvest activities. Early successional 
Table 8. Potential fire hazard by ownership, modeling year 1 and year 50

\begin{tabular}{|c|c|c|c|c|}
\hline Ownership & $\begin{array}{c}\text { Percentage of ownership } \\
\text { having high-severity fire } \\
\text { potential } \\
\text { (model year } 1 \text { ) }\end{array}$ & $\begin{array}{l}\text { 95th percent confidence } \\
\text { interval (model year 1) } \\
\text { lower / upper }\end{array}$ & $\begin{array}{c}\text { Percentage of ownership } \\
\text { having high-severity fire } \\
\text { potential } \\
\text { (model year } 50)\end{array}$ & $\begin{array}{l}\text { 95th percent confidence } \\
\text { interval (model year 50) } \\
\text { lower / upper }\end{array}$ \\
\hline All Forest Service & 62.0 & $61.8 / 62.2$ & 37.4 & $37.0 / 37.8$ \\
\hline All State & 78.0 & $77.9 / 78.1$ & 77.7 & $75.9 / 79.5$ \\
\hline All Corporate & 75.1 & $74.9 / 75.3$ & 76.2 & $74.1 / 78.4$ \\
\hline \multicolumn{5}{|l|}{ Forest Service RD } \\
\hline Chemult & 75.0 & $74.9 / 75.1$ & 47.4 & $46.8 / 48.0$ \\
\hline Chiloquin & 57.8 & $57.3 / 58.3$ & 31.5 & $31.0 / 32.1$ \\
\hline Klamath & 44.2 & $44.1 / 44.3$ & 30.2 & $29.6 / 30.8$ \\
\hline \multicolumn{5}{|l|}{ State forests } \\
\hline Sun Pass & 81.0 & $80.8 / 81.2$ & 72.8 & $69.8 / 75.8$ \\
\hline Gilchrist & 73.4 & $73.3 / 73.5$ & 85.4 & $84.4 / 86.3$ \\
\hline \multicolumn{5}{|l|}{ Corporate owners } \\
\hline $\mathrm{PCl}$ & 75.4 & $75.2 / 75.7$ & 76.3 & $73.3 / 79.2$ \\
\hline $\mathrm{PC} 2$ & 79.0 & $78.7 / 79.3$ & 77.2 & $76.6 / 77.8$ \\
\hline PC3 & 61.3 & $59.8 / 62.8$ & 74.1 & $72.6 / 75.6$ \\
\hline PC4 & 84.2 & $84.1 / 84.4$ & 74.9 & $72.8 / 76.9$ \\
\hline
\end{tabular}

vegetation types increased most on state (Gilchrist) and private corporate (PC4) lands, associated with harvest and wildfire. The Klamath District also experienced a strong increase in early successional vegetation types. The area of open canopy forest increased dramatically on state lands as a result of harvest on the Sun Pass State Forest. Overall, the share of the landscape in larger sized trees increased on both FWNF and private corporate lands. The increase in larger trees on corporate lands was the result of changes on one ownership (PC1), where roughly half of the ownership consists of 30 -year-old plantations that are maturing. The area of larger trees declined on all other private corporate ownerships. Larger trees declined on the Sun Pass State Forest as a result of harvest in older, more mature stands, but increased on Gilchrist owing to maturing stands.

Potential fire hazard declined over 50 years under current management on FWNF lands, but stayed about the same for all state and private corporate owners (Fig. 6, Table 8). The rates of decline were similar across ranger districts, but the Klamath had a somewhat slower rate of decline in the last 20 years of the simulation. The overall potential fire hazard for state lands declined over the first 10 years with the harvest of denser older stands, but then increased gradually for about 30 years. However, on Sun Pass, it had declined by year 50 whereas on Gilchrist, it had increased. Private corporate ownerships varied in potential fire-hazard trajectories. The most variable was PC3, where potential fire hazard declined strongly with heavy harvest during the first 10 years before increasing again as vegetation and fuels built up in later decades. Potential fire hazard on the other individual ownerships did not change much over the simulation period, although PC4 saw overall declines by year 50 (Table 8). Interestingly, high-severity fire potential was similar on all four private corporate ownerships in year 50 , despite differences in total change. This result may reflect similarities in management among these owners with regard to factors that affect fire potential in the model (e.g., absence of prescribed fire); insufficient sensitivity in the fuel models to variation in management regimes; or comparable proportions of vegetation classes on these ownerships that burn as high-severity fire under weather conditions simulated by the model.

Fig. 6. Mean annual area (percentage) and 95\% confidence interval (dashed lines) of potential high-severity fire (hazard) under current management vs. time, between and within ownership categories. Based on 15 model replicates.

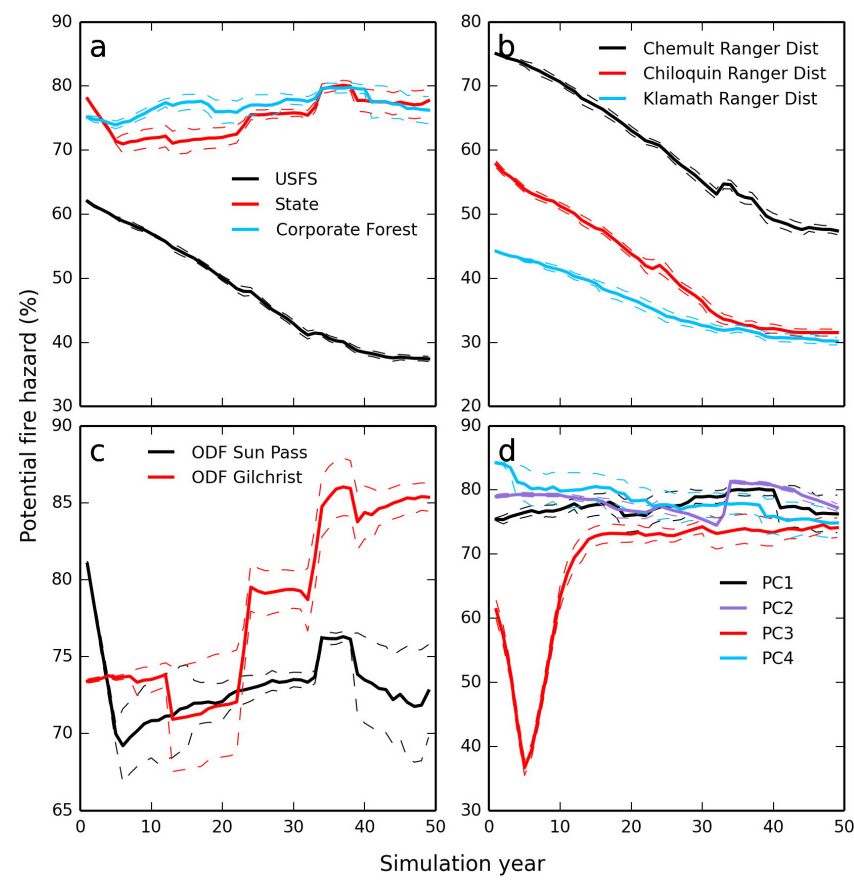

The median amount of potential fire loss for the worst fire years (top $10 \%$ of annual area burned) was highest for private corporate and lowest for state lands (Fig. 7). There was little difference 
between the FWNF ranger districts, or between individual corporate owners, with the exception of PC2, which experienced very little fire loss. Part of the explanation for differences among and within ownerships may relate to the total area of the ownership. Smaller parcels such as the Sun Pass State Forest (7323 ha) would be less likely to experience high-severity fire simply because of small areas exposed to fire starts or spread.

Fig. 7. Box and whisker plots of for annual percentage of ownership experiencing stand-replacing wildfire (loss) in all fire years under current management, between and within ownership categories, for the top $10 \%$ of worst fire years $(n=$ 75 out of 750 replication years). Red line $=$ median percentage of ownership burned; blue box $=25$ th to 75 th quartiles.
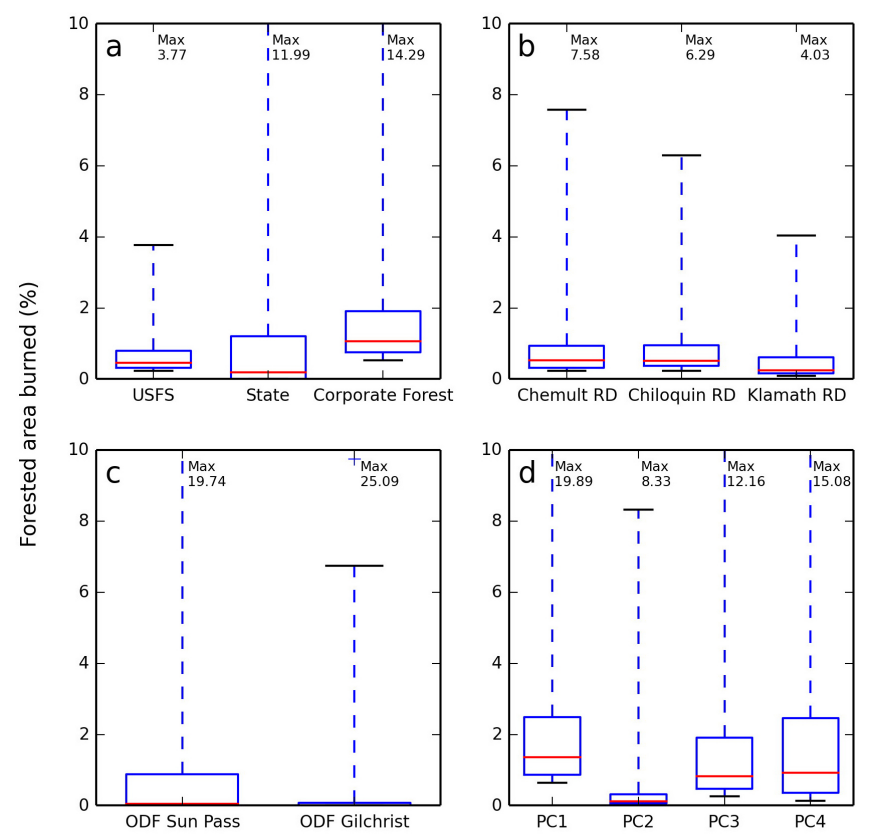

Potential fire loss in private corporate forests was disproportionally higher than what would be expected based on their occurrence in the study area and for all of the management classes considered (Table 9). State lands burned in proportion to their availability whereas federal lands burned significantly less than their occurrence. This finding is in agreement with overall results that showed higher median fire loss for private corporate forests.

Timber harvest achieves important forest management objectives, influences fire hazard, production of ecosystem services, and is a potential revenue source. The ownerships differed in the amount of timber they harvested annually as well as the prominence of timber harvest in their management actions. We found differing abilities to meet current timber targets between owners and differing patterns in projected timber harvest over time. The FWNF was able to maintain current timber harvest levels during the life of the simulation (Fig. 8). Private corporate owners fall rapidly from high production levels in the short term and then oscillate at lower total production levels between model years 10 and 50. This pattern largely reflects the harvest plan of one owner
(PC3), who seeks to remove as much volume as possible during the next 10 years. This approach results in a cycling of volume production as available harvest volume disappears and then recovers in later decades when forests mature. The cycle of volume production assumes that PC3 lands will continue to be used for timber production, which may not occur if its forests are heavily cut in the short run and the land is sold or used for nontimber purposes. Projected timber harvest on state lands declines steadily over the period to a final harvest volume that is roughly $50 \%$ of current harvest. This occurs because harvest on Sun Pass shifts from a focus on first-entry thinning of smaller trees, to secondentry group selection cuts of bigger, higher-value trees.

Table 9. Fire incidence indices for different ownership types and management layers. Fire incidence values range between -1 and 1 , with $\mathrm{I}_{\mathrm{om}}=0$ when the land ownership burns in proportion to its availability (extent) on the landscape. Negative values of fire incidence indicate that the ownership is burning less than expected given its availability, whereas positive values imply that the ownership is burning more than what is expected given its availability

\begin{tabular}{lccc}
\hline \hline Iom & Federal & State & Corporate \\
\hline All lands & -0.39 & -0.16 & 0.41 \\
Forested & -0.41 & -0.17 & 0.42 \\
Fire-prone & -0.4 & -0.2 & 0.40 \\
PVTs & & & \\
\hline
\end{tabular}

Fig. 8. Change in total merchantable harvest volume between model simulation years 1 and 50, between and within forest ownership categories. Dashed lines indicate upper and lower $95 \%$ confidence intervals for 15 replications.

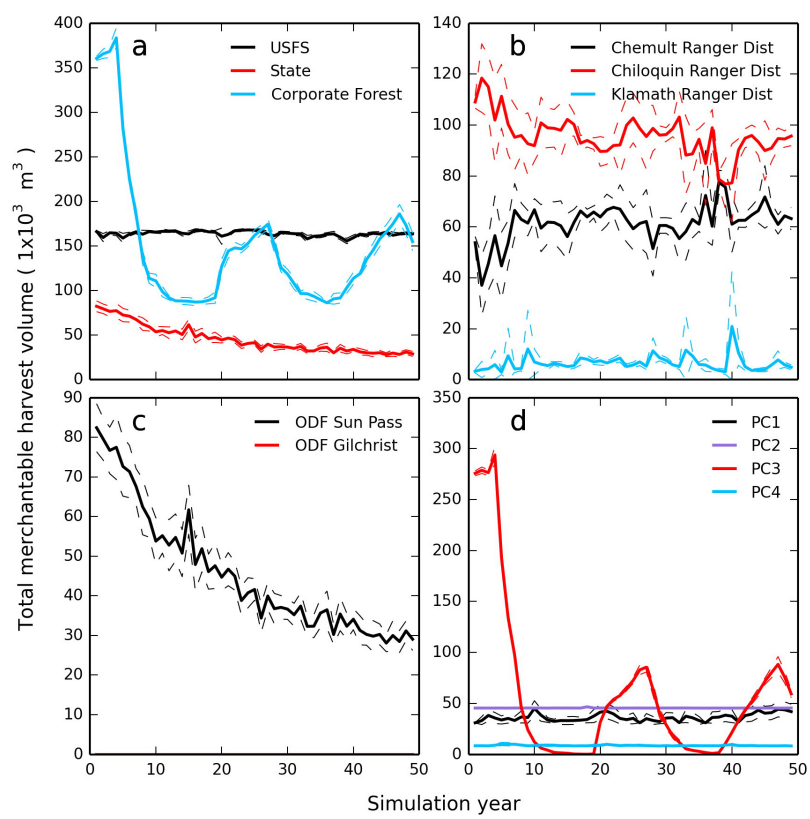




\section{DISCUSSION}

Our results indicate that large actors in the fire-prone forest landscape of southcentral Oregon exhibit response diversity in managing their forestlands to reduce wildfire hazard and losses to high-severity wildfire. As stated in the Introduction, the outcomes of response diversity among people are largely unstudied, and its implications for social-ecological resilience and adaptation not well documented (Leslie and McCabe 2013), especially for fire-prone forests (but see Spies et al. 2007). Our modeling work enabled us to examine the consequences of different forest and fire management approaches by ownership.

We found that potential fire hazard was lower on FWNF lands than that on state and private corporate lands, and FWNF lands exhibited a substantial decrease in potential fire hazard over time, unlike most other ownerships. This finding counters the widespread perception by many outside groups (e.g., Oregon Forest Resources Institute 2010), and among actors interviewed in this study that Forest Service lands exhibit higher fire hazard than state and private corporate lands. It also counters the perception among some large actors that wildfire fuels mitigation by the Forest Service is ineffective. As one private corporate interviewee stated:

Cuz as you know, I mean, government grounds have just been basically sittin' idle. They go out and they do some underburns, which just generates more dead trees and increases more insects. Face it, they've thrown out the forestry textbooks and have gone to this politically correct forestry, which is why we have all these ... problems.

We attribute this finding to several things. First, mechanical treatments such as timber harvest do not necessarily reduce fire hazard; timber harvest can increase fire hazard if activity fuels are not treated with prescribed fire (Raymond and Peterson 2005). Fire hazard is related to ground fuels (duff), surface fuels (e.g., litter, grasses, low shrubs), ladder fuels, and crown fuels. Of this set, surface fuels, which are not typically reduced by timber harvest, are considered the most hazardous in many forests (Stephens et al. 2012, Calkin et al. 2014, North et al. 2015). The use of prescribed fire by Forest Service managers to treat surface fuels is especially effective at reducing the likelihood of highseverity fire relative to mechanical treatments alone (Stephens et al. 2012). This finding suggests that fortress protection is not an ecologically adaptive strategy for mitigating wildfire.

Second, potential fire loss relates to the size of trees (bigger trees are more resistant and resilient to wildfire (Agee and Skinner 2005)) and was lower on federal lands than on private corporate lands. It was not surprising that the highest percentage of large and giant trees occurred on federal lands, which also had the highest percentage of land in resilient forest structure, nor that both increased over time given differences in management goals and policies. Some private corporate owners also had a relatively high proportion of big trees owing to past management (PC3 and PC4), as did Sun Pass; however this proportion declined over time under current management.

Forest Service management emphasizes dry forest restoration to encourage development of large ponderosa pine trees in particular. Additionally, concerns over harvesting older forest on federal lands led to policies in the 1990s that largely eliminated harvesting of trees $>53 \mathrm{~cm}$ in diameter (the " 21 -inch rule") on national forests in the region. These policies, together with overall reductions in timber harvest levels on federal lands in the Pacific Northwest in the 1990s, and changing global wood products markets and milling technology, contributed to a shut-down of mills that process large-diameter trees, or retooling of mills to process smaller-diameter logs. Changes in milling infrastructure and reduced demand for large timber mean big trees do not bring the high prices they once did. The result: state and private corporate owners have less financial incentive to grow them. Fear that the one local mill that still processes large-diameter logs may close due to insufficient supply (federal lands comprise over half of the study area) makes managing for large trees on state and private corporate lands risky business. As one private corporate interviewee stated:

\section{...that's one of the problems I see in the future - is ... how long we are going to be able to hold the old-growth component in our timber stands because ... there will not be a market for it.}

A third finding pertains to the simulated area burned by highseverity fire on each ownership over time. We found that in the worst fire years, the median annual potential fire loss was somewhat higher on private corporate lands than on the FWNF and state lands. But the single worst fire year in the model runs burned $12-14 \%$ of state and private corporate forestlands (and higher on some individual ownerships), compared with just under $4 \%$ of FWNF lands (Fig. 7).

The large size of Forest Service land means more area will burn there; however, our analysis of fire incidence (Table 9) showed that the FWNF burned less than expected given their availability in the study area, in contrast to private corporate forests that burned disproportionately more than their abundance on the landscape. The relatively low incidence of fire on FWNF lands compared with corporate lands suggests that, although land area matters, overall burned area (and mostly fire incidence) is the spatial outcome of a combination of deterministic variables such as topography, vegetation, and management combined with stochastic variables such as the spatial and temporal patterns of ignitions and meteorological conditions.

The higher fire hazard on private corporate lands compared with FWNF lands can be explained by the simulated management activities and forest structure. From a management standpoint, postharvest fuel models in corporate lands are associated with high-load timber litter slash. This fuel model will characterize the landscape until a disturbance takes place, or up to the point that the fuel model returns to the preharvest baseline (10 years). In federal lands, policy is to apply prescribed fire after harvesting, which will trigger a timber litter fuel model that is characterized by lower fuel loads than in private corporate forest. Therefore holding all other factors equal, a given IDU in federal lands that had prescribed fire after harvest will have lower fuel loads than a corporate IDU, thereby lowering simulated flame length. Moreover, from the forest structure standpoint, corporate forest has younger, smaller trees than federal lands. These smaller trees will be more sensitive to fire, and for a given flame length, will more likely be killed than larger, older trees. 
Taking into account that overall, we found that private corporate forests had higher (and nondiminishing) potential fire hazard due to higher fuel loads and younger stands, when an ignition occurs under meteorological conditions that favor fire spread, corporate areas are very likely to experience large burned areas as standreplacing fire, as reflected by the potential fire loss and fire incidence metrics. This is particularly true when considering long simulation timeframes (e.g., 50 years). It is important to emphasize, however, that (1) this effect is highly stochastic, and (2) these findings do not take into account differences in degree of, and capacity for, fire suppression among owners. Nevertheless, fire-suppression activities may not be effective in the case of large, high-intensity wildfire. Our results should be interpreted as potential fire loss given fuelbed and forest conditions.

\section{Economic considerations}

These findings point to the importance of having local markets for small-diameter biomass. Markets for removed biomass can be more robust and help overcome the cost barrier of hazardous fuel reduction when infrastructure to use biomass (either producers or end users) is close to forestlands where treatments take place (Becker et al. 2009, Nielson-Pincus et al. 2013). Local markets, rather than distant ones, have the benefit of reducing the cost of transporting biomass from the woods to the processor, which is a key hurdle in using biomass generated from forest management. Although eastern Oregon has a relatively diverse wood-processing infrastructure, the number of mills generally has declined over the past two decades (Swan et al. 2013). Furthermore, although there are some specialty facilities that turn small-diameter biomass into market products (e.g., chips, firewood, or animal bedding), those facilities are located far apart and have limited capacity. As one private corporate owner that is currently cutting as much timber as it can stated:

The biggest problem in eastern Oregon is-well, you've seen how, oh gee, since the '80s how many mills have just dropped off the radar screen.... I mean, it's a huge mortality in the timber industry... That's why I say really to protect your investment you need to harvest your pine while you can do something with it.... Face it, private timberland usually is an investment to make money, and if you have no avenue to make money then it makes for a very poor investment...people are having to react to the cards they're dealt I guess.

This logic can lead to a positive feedback loop (Fig. 9) that has negative outcomes for ecological values (forest conversion to realestate development), fire resilience (more people move into the WUI), forest-based jobs, and working forestlands. One way to break the loop is for government to intervene (as with the Gilchrist State Forest), but this requires a major investment of public funds. In contrast, strong chip and biomass markets can reduce wildfire hazard by making possible the economical removal of smalldiameter trees and shrubs that need thinning (Fig. 10), which in turn may make surface fuel treatments more affordable. If woodprocessing infrastructure declines beyond the threshold needed to support a viable local forestry industry and no new markets emerge, the ability of private corporate actors to retain their forestlands and the ability of all actors to reduce hazardous fuels diminish.
Fig. 9. Positive feedback loop associated with loss of mill infrastructure.

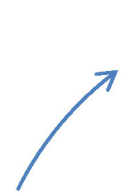

Log supply from

state lands too small to compensate; log supply from federal lands unreliable

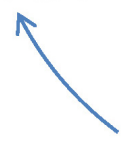

Private corporate owners overharvest and sell cutover land for real estate development
Fig. 10. Negative feedback loop in which wildfire hazard decreases on forestlands.

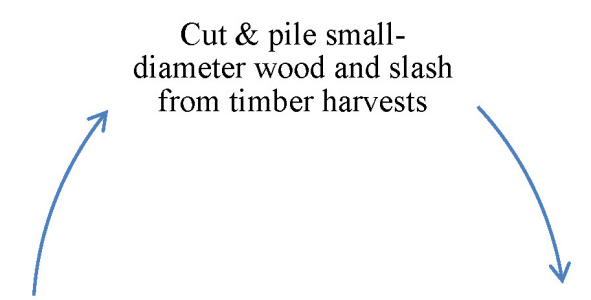

Fire hazard reduced at limited cost, or with revenue, to forest owner
Chip/biomass market strong, piles chipped, sold, removed

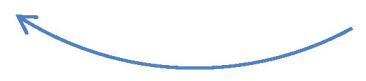

\section{Adaptation and resilience in fire-prone forest ecosystems}

Here, we return to the first research expectation stated in the Introduction. We expected that response diversity in forest and fire management among landowners in our study area would contribute to environmental heterogeneity, and in doing so, enhance forest resilience to high-severity wildfire.

\section{Heterogeneity}

Response diversity among large forest landowners in our study area leads to forest heterogeneity, as the forest structure and wildfire analyses and simulation results indicate. Heterogeneity is often thought to enhance resilience (Walker et al. 2006, Norberg 
et al. 2008, Cumming et al. 2013, Kotschy et al. 2015). Yet, our analysis found that most forest ownerships do not exhibit forest structure and potential wildfire characteristics that make them resilient to high-severity fire currently, or in the future under current management. Historically, about $75 \%$ of this landscape was composed of large or giant trees $(>50 \mathrm{~cm} \mathrm{dbh})$ having understories that were probably a matrix of relatively open conditions with patches of denser, multilayered forest (Hagmann et al. 2013, Merschel et al. 2014, Spies et al. 2017). The rest of the landscape would have been in varying stages of succession following high-severity fire, which was uncommon in this low to mixed-severity fire regime-dominant landscape. The historic landscape was resilient to fire in that most large trees would have survived fires, and understories would have persisted in a shifting mosaic of densities and species. However, the present lack of large trees and predominance of dense understories, large patches of young plantations, and other smaller stature vegetation we found create a new heterogeneity that is much less resilient to wildfire and other disturbances than would have been the case historically. Heterogeneity in forest ownership and management does not convey resilience if that heterogeneity includes vegetation conditions that are not resilient to wildfire. Thus, simple rules or theories for resilience based on heterogeneity are not valid and must be based on knowledge of the environmental conditions that comprise ecological heterogeneity.

Despite lacking characteristics that make them resilient to highseverity fire currently, the FWNF, Sun Pass State Forest, and some private corporate lands (PC4) have the building blocks for developing resilient forest structure in the near future. Although their forestlands do not occur in the western half of the study area, and therefore, were not modeled here, a forest structure analysis previously conducted for PC5 found the same on that ownership (Charnley et al. 2012). That is, these ownerships currently contain a relatively high proportion of big trees, which can take decades to centuries to develop. Interestingly, these particular land ownerships have been under management by the same federal, state, or private corporate owner for a much longer period than the other individual ownerships in the study area (Appendix 2). This finding underscores the importance of longterm investment in forest ownership and management as an indicator of wildfire resilience.

\section{Adaptation}

The concept of resilience is rooted in the idea of response to or recovery from disturbance or loss. Adaptation can be defined as the capacity of people - including organizations and institutions - to respond to or recover from disturbance or environmental change and to shape it in a manner that promotes the sustainability and resilience of a CHANS (Berkes et al. 2003, Folke 2006). Even with fuel treatments at landscape scales and restoration of resilient forest structure, high-severity wildfire and undesirable losses will occur, especially as climate change alters fire behavior and vegetation conditions in the region (Halofsky et al. 2014). Such fires incur substantial financial losses for owners whose forestlands burn because damaged trees take a long time to grow back, and postfire replanting and reforestation costs can be high. Forest owners whose lands do not burn also pay a price: wildfires can flood markets with salvage timber, which can reduce stumpage prices and make it harder to market living trees. How do large actors respond to and recover from high-severity wildfire?
Federal and state forest owners are likely to recover more easily than private corporate owners because they are part of a larger network of public lands that help offset the social and economic impacts of fire in any one locale. They may also receive public funding to support postfire recovery. In contrast, private corporate actors may experience financial stress that could lead to a tipping point, resulting in bankruptcy or land sales. If land sales cause changes in land use, another outcome could be mill closure from reduced log supply, contributing to the positive feedback loop depicted in Fig. 9. This response is especially concerning because of our finding that private corporate lands are generally the least resilient to high-severity wildfire.

Private corporate actors in our study had different capacities for responding to financial stress, as experienced when wood products markets are poor. PC4 avoids overharvesting to meet revenue goals by having a diversified business strategy that includes owning and managing ranchlands that also generate revenue:

That's one great thing about having a cattle ranch and
timber side because...last year, the market was up enough,
and we did log a little bit but honestly, last year, the cow
market was good enough that with this little family, you
probably could have gotten away with only cutting a
million feet.

PC5 has ready access to varied processing infrastructure it controls and also owns forestlands outside the local area, both of which provide a buffer to financial stress. PC1 shifts its harvest practices. When chip markets are up, it can meet revenue goals by heavily harvesting plantations in need of thinning. When chip markets are down, it meets those goals by harvesting bigger, more valuable trees from natural stands. PC2 and PC3 are part of much larger, financially diversified corporations; if their lands don't generate desirable returns, they may be sold. Large private corporate ownerships have a history of turnover in the study area over the past 50 years (Appendix 2). Although cutting, selling, and moving on may be good for these private corporate owners, doing so does not promote social-ecological resilience to wildfire locally.

\section{Leverage points for change}

Our second research expectation was that response diversity among forest landowners would make possible comparative analysis to identify adaptive management strategies and barriers to adaptation, providing insights for how to increase ecosystem resilience to high-severity wildfire. What, then, are the leverage points in the system for change to overcome barriers to adaptation and increase forest resilience to high-severity wildfire? The following list emerged from our findings.

Retain and develop market infrastructure for wood products of all types

Large actors in the study area all rely on wood products production and markets to stay in business and/or help finance forest restoration treatments. A reliable supply of products from all ownerships is needed to retain existing infrastructure and expand new infrastructure. Our modeling work found that most of the large actors in the study area can sustain their current timber production volumes over the next 50 years. If restoration treatments to increase wildfire resilience were accelerated (Barros et al. 2017, Spies et al. 2017), it might still be possible to provide 
a sustainable supply of wood while maintaining a resilient forest structure.

\section{Incentivize growth of big trees on private corporate lands that currently lack them}

Big trees are more resilient to high-severity fire, but are scarce on private corporate lands. Private corporate owners, who have concerns about the long-term capacity of local mills to process large trees and who don't see a price differential for large logs relative to small logs, currently have little economic incentive to grow large trees. In this CHANS, signals in the human system and resulting actor decision making influence the ecological conditions on private corporate lands. Private landowners would have greater incentive to grow large trees if they had confidence that the infrastructure would be in place to process the large logs produced from future forest stands and if large logs were more valuable relative to small logs.

Because federal landowners manage over half of the landscape, federal landowner actions have a strong influence on the market for large logs faced by public and private corporate landowners. Current federal policies that limit harvests to trees $<53 \mathrm{~cm}$ in diameter on federal lands reduce the number of large logs delivered to local mills. That policy could be reconsidered, especially for large but relatively young grand (Abies grandis) and white fir (Abies concolor) trees that have developed under fire exclusion, and are currently present at higher densities than they were historically (Hagmann et al. 2013). Increased production of large logs may, at a minimum, support continued mill infrastructure to process large logs and may also spur on new markets with differential pricing for large logs. Removing large grand and white fir commonly occurs in forest restoration projects on the FWNF by amending the forest plan, which limits removal to trees $<53 \mathrm{~cm}$ in diameter. However, grand and white fir are presently less desirable than pine at several local mills that focus primarily on pine and Douglas-fir logs. Harvesting of large pine and Douglas-firs from federal land is more problematic because these are the backbone of fire-resilient forests. It may be possible to harvest low levels of these trees to help subsidize fuel reduction programs on federal lands, but the ecological and economic feasibility of such a policy has not been evaluated. Other economic incentives for growing bigger trees on private lands may also be useful, for example, opportunities to market carbon credits accrued from long-rotation forest management that increases carbon sequestration relative to business as usual.

\section{Make financial assistance available to private corporate owners for reducing fire hazard and recovery following wildfire}

Financial assistance programs for private corporate owners would help them reduce fire hazard by thinning nonmerchantable, smalldiameter trees and doing mastication and other treatments. Financial assistance is also needed to help them recover from wildfire, which often starts on federal ownerships and may lead to financial tipping points.

Develop policies and programs that support the use of prescribed fire on private corporate and state lands

Surface fuel treatments are needed to reduce fire hazard, and prescribed fire is an ecologically important and relatively economical tool for achieving this goal. State and private corporate owners identified several reasons for not using this tool. It may be difficult to address all of their concerns, but some indicated willingness to use prescribed fire if key legal and financial constraints were overcome.

Strengthen social networks for addressing wildfire

Wildfire is a landscape-scale disturbance process and, as such, is best addressed through coordinated activities that combine to alter landscape-scale conditions. In mixed-ownership landscapes, where fire and fuel management on one ownership can affect conditions faced by neighboring owners, collective management actions are often needed when individual landowners wish to reduce the potential for high-severity fire. Developing strategies for wildfire mitigation across all ownerships requires communication, coordination, and collaboration, in addition to analysis of wildfire exposure through transmission across the landscape (Ager et al. 2014). Strong social networks may provide a foundation for this collective action. It would be possible to integrate a social network analysis into our agent-based model to examine how social networks influence landscape outcomes with regard to wildfire resilience, although we did not do so. A social network analysis carried out as part of the FPF project found that there is not a high degree of overlap between networks of forest and fire management organizations in our study area, but there are strong social ties within these two organizational networks (Fischer and Jasny 2017). Large landowner actors who were the focus of this research all have an interest in collaborating to address wildfire and fuel problems, and most were members of collaborative groups that engage forest management issues. A central component of the FPF project is to undertake outreach to actors within these social networks by disseminating research findings to them and conducting future scenario modeling using the agent-based model we developed. Through these efforts, we are providing additional scientific information and modeling platforms to explore alternative management scenarios. This work supports the strengthening of existing collaborations and encourages more interaction between forest and fire management networks to help local actors build their capacity to manage forestlands for wildfire resilience.

\section{CONCLUSIONS}

We used empirical data and modeling of actor behavior in a fireprone forest CHANS to evaluate a diversity of approaches to forest management by large actors who share a multiownership landscape, and to gain insight about resilience to high-severity wildfire. Our methods point to the importance of looking beyond the present to future trajectories of change to fully understand the implications of current natural resource management practices for adaptation and social-ecological resilience to natural disturbances.

We found that Forest Service management was likely to produce forest conditions most resilient to high-severity wildfire. Private corporate owners are a heterogeneous group, making generalization difficult. Nevertheless, private corporate ownerships exhibited the lowest resilience to wildfire over time and had the greatest constraints to fire hazard reduction, largely financial but also attitudinal.

Examining response diversity provided insights into how different management strategies and associated forest conditions affect resilience to wildfire at landscape and within-ownership scales. By looking at diversity within ownership categories we also 
identified the important role of history in influencing current resilience to wildfire. Heterogeneity in forest conditions that are the outcome of response diversity does not necessarily lead to wildfire resilience - the characteristics and relative frequency of the components of heterogeneity matter. Thus, heterogeneity as key to social-ecological resilience should be viewed critically.

It is important to ask not only resilience of what, to what (Carpenter et al. 2001), but resilience for what? Managing to achieve the goal of resilience of fire-prone forest ecosystems to high-severity wildfire is important for sustaining a particular set of social values, including protection of homes and structures, protection of timber assets and production, protection of scenic quality and recreation opportunities, and protection of certain ecological values. However, there exist potential trade-offs in managing for forest resilience to wildfire related to biodiversity, carbon storage, and timber production (Spies et al. 2017).

Response diversity in forest management among actors is an inevitable result of differences in landscape conditions and management histories on different ownerships, management goals and institutions, and social, economic, and cultural drivers that influence actor decisions. By identifying landscape features and management approaches on certain ownerships that have better outcomes for forest resilience to wildfire and appear more adaptive, we do not imply that other actors should, or can, follow suit. Rather, we point to the opportunities for learning by actors who share the goal of reducing losses to wildfire that studying response diversity and its outcomes provides. These actors can then identify practices they may wish to adopt, experiment with, and adapt to fit their particular management context, which may call for policy change. Enabling this process is one way to increase adaptive capacity and resilience of fire-prone forest ecosystems to high-severity wildfire.

Responses to this article can be read online at: http://www.ecologyandsociety.org/issues/responses. $\mathrm{php} / 8753$

\begin{abstract}
Acknowledgments:
This research was supported by a National Science Foundation, Coupled Human and Natural Systems Program Grant (CHH-1013296) and National Fire Plan funding from the United States Forest Service. The authors thank Kendra Wendel who provided essential help with data analysis and manuscript preparation. We also thank our many interviewees who participated in this study and graciously shared their time and knowledge with us. We thank the Forests-People-Fire research team for their intellectual and technical contributions to this research as it evolved. Alan Ager, John Bailey, and two anonymous reviewers provided valuable comments on drafts of the manuscript, and we are grateful to them for helping us strengthen it.
\end{abstract}

\section{LITERATURE CITED}

Agee, J. K., and C. N. Skinner. 2005. Basic principles of forest fuel reduction treatments. Forest Ecology and Management 211 (1):83-96. http://dx.doi.org/10.1016/j.foreco.2005.01.034
Ager, A. A., M. A. Day, M. A. Finney, K. Vance-Borland, and N. M. Vaillant. 2014. Analyzing the transmission of wildfire exposure on a fire-prone landscape in Oregon, USA. Forest Ecology and Management 334:377-390. http://dx.doi.org/10.1016/ j.foreco.2014.09.017

An, L. 2012. Modeling human decisions in coupled human and natural systems: review of agent-based models. Ecological Modelling 229:25-36. http://dx.doi.org/10.1016/j.ecolmodel.2011.07.010

Barros, A. M. G., A. A. Ager, M. A. Day, H. K. Preisler, T. A. Spies, E. White, R. Pabst, K. A. Olsen, E. Platt, J. D. Bailey, and J. P. Bolte. 2017. Spatiotemporal dynamics of simulated wildfire, forest management, and forest succession in central Oregon, USA. Ecology and Society 22(1):24. https://doi.org/10.5751/ ES-08917-220124

Becker, D. R., D. Larson, and E. C. Lowell. 2009. Financial considerations of policy options to enhance biomass utilization for reducing wildfire hazards. Forest Policy and Economics 11 (8):628-635. http://dx.doi.org/10.1016/j.forpol.2009.08.007

Bennett, E. M., G. S. Cumming, and G. D. Peterson. 2005. A systems model approach to determining resilience surrogates for case studies. Ecosystems 8:945-957. http://dx.doi.org/10.1007/ s10021-005-0141-3

Berkes, F., J. Colding, and C. Folke. 2003. Introduction. Pages 130 in F. Berkes, J. Colding, and C. Folke, editors. Navigating socialecological systems: building resilience for complexity and change. Cambridge University Press, Cambridge, UK. http://dx.doi. org/10.1017/cbo9780511541957.003

Berkes, F., and C. Folke. 1998. Linking social and ecological systems for resilience and sustainability. Pages 1-26 in F. Berkes, C. Folke, and J. Colding, editors. Linking social and ecological systems: management practices and social mechanisms for building resilience. Cambridge University Press, Cambridge, UK.

Biggs, R., M. Schluter, and M. L. Schoon. 2015. Principles for building resilience: sustaining ecosystem services in socialecological systems. Cambridge University Press, Cambridge, UK. http://dx.doi.org/10.1017/cbo9781316014240

Burscu, T. K., J. S. Halofsky, J. S. Bisrat, S. A. Christopher, T. A. Creutzburg, E. B. Henderson, M. A. Hemstrom, F. J. Triepke, and M. Whitman. 2014. Dynamic vegetation modeling of forest, woodland, shrubland, and grassland vegetation communities in the Pacific Northwest and Southwest Regions of the United States. Pages 15-69 in J. E. Halodsky, M. K. Crutzberg, and M. A. Hemstrom, editors. Integrating social, economic, and ecological values across large landscapes. U.S. Forest Service General Technical Report PNW GTR-896.

Calkin, D. E., J. D. Cohen, M. A. Finney, and M. P. Thompson. 2014. How risk management can prevent future wildfire disasters in the wildland-urban interface. Proceedings of the National Academy of Sciences 111(2):746-751. http://dx.doi.org/10.1073/ pnas. 1315088111

Calkin, D. E., M. P. Thompson, and M. A. Finney. 2015. Negative consequences of positive feedbacks in U.S. wildfire management. Forest Ecosystems 2(9):1-10.

Carpenter, S., B. Walker, J. M. Anderies, and N. Abel. 2001. From metaphor to measurement: resilience of what to what? Ecosystems 4:765-781. http://dx.doi.org/https://doi.org/10.1007/s10021-001-0045-9 
Charnley, S., M. R. Poe, A. A. Ager, T. A. Spies, and E. K. Platt. 2015. A burning problem: social dynamics of disaster risk reduction through wildfire mitigation. Human Organization 74 (4):329-340. http://dx.doi.org/10.17730/0018-7259-74.4.329

Charnley, S., T. A. Spies, and E. K. Platt. 2012. Variation in fire hazard and forest management across ownerships in central Oregon. Fifth Annual International Fire Ecology and Management Congress, Portland, Oregon, USA.

Collins, B. M., S. L. Stephens, J. J. Moghaddas, and J. Battles. 2010. Challenges and approaches in planning fuel treatments across fire-excluded forested landscapes. Journal of Forestry 108 (1):24-31.

Cumming, G. S., P. Olsson, F. S. I. Chapin, and C. S. Holling. 2013. Resilience, experimentation, and scale mismatches in social-ecological landscapes. Landscape Ecology 28:1139-1150. http://dx.doi.org/10.1007/s10980-012-9725-4

Elmqvist, T., C. Folke, M. Nystrom, G. Peterson, J. Bengtsson, B. Walker, and J. Norberg. 2003. Response diversity, ecosystem change, and resilience. Frontiers in Ecology and the Environment 1(9):488-494. http://dx.doi.org/10.1890/1540-9295(2003)001[0488: rdecar]2.0.co;2

Fettig, C., K. D. Klepzig, R. F. Billings, A. S. Munson, T. E. Nebeker, J. F. Negron, and J. T. Nowak. 2007. The effectiveness of vegetation management practices for prevention and control of bark beetle infestations in coniferous forests of the western and southern United States. Forest Ecology and Management 238 (1):24-53. http://dx.doi.org/10.1016/j.foreco.2006.10.011

Finney, M. A. 2001. Design of regular landscape fuel treatment patterns for modifying fire growth and behavior. Forest Science 47(2):219-228.

Finney, M. A. 2002. Fire growth using minimum travel time methods. Canadian Journal of Forest Research 32:1420-1424. http://dx.doi.org/10.1139/x02-068

Fischer, A. P., and L. Jasny. 2017. Capacity to adapt to environmental change: evidence from a network of organizations concerned with increasing wildfire risk. Ecology and Society 22 (1):23. https://doi.org/10.5751/ES-08867-220123

Folke, C. 2006. Resilience: the emergence of a perspective for social-ecological systems analyses. Global Environmental Change 16(3):253-267. http://dx.doi.org/10.1016/j.gloenvcha.2006.04.002

Foster, D. F., F. Swanson, J. Aber, I. Burke, N. Brokaw, D. Tilman, and A. Knapp. 2003. The importance of land-use legacies to ecology and conservation. BioScience 53(1):77-88. http://dx.doi. org/10.1641/0006-3568(2003)053[0077:tiolul]2.0.co;2

Gunderson, L. H., C. S. Holling, L. Pritchard, and G. D. Peterson. 2002. Understanding resilience: theory, metaphors, and frameworks. Pages 3-20 in L. H. Gunderson and L. Pritchard, editors. Resilience and the behavior of large-scale systems. Island Press, Covelo, CA.

Hagmann, R. K., J. F. Franklin, and K. N. Johnson. 2013. Historical structure and composition of ponderosa pine and mixed-conifer forests in south-central Oregon. Forest Ecology and Management 304:492-504. http://dx.doi.org/10.1016/j.foreco.2013.04.005
Halofsky, J. S., J. E. Halodsky, T. Burscu, and M. A. Hemstrom. 2014. Dry forest resilience varies under simulated climatemanagement scenarios in a central Oregon, USA landscape. Ecological Applications 24(8):1908-1925. http://dx.doi. org/10.1890/13-1653.1

Hessburg, P. F., D. J. Churchill, A. J. Larson, R. D. Haugo, C. Miller, T. A. Spies, M. P. North, N. A. Povak, R. T. Belote, P. H. Singleton, W. L. Gaines, R. E. Keane, G. H. Aplet, S. L. Stephens, P. Morgan, P. A. Bisson, B. E. Rieman, R. Salter, and G. H. Reeves. 2015. Restoring fire-prone Inland Pacific landscapes: seven core principles. Landscape Ecology 30(10):1-31. http://dx.doi. org/10.1007/s10980-015-0218-0

Huang, Q., D. C. Parker, T. Filatova, and S. Sen. 2014. A review of urban residential choice models using agent-based modeling. Environment and Planning B: Environment and Design 41:661-689. http://dx.doi.org/10.1068/b120043p

Jacobs, J. 1974. Quantitative measurement of food selection: a modification of the forage ratio and Ivlev's electivity index. Oecologia 14(4):413-417. http://dx.doi.org/10.1007/bf00384581

Janssen, M. A. 2002. Introduction. Pages 1-10 in M. A. Janssen, editor. Complexity and ecosystem management: the theory and practice of multi-agent systems. Edward Elgar, Northampton, Massachusetts, USA.

Kotschy, K., R. Biggs, T. Daw, C. Folke, and P. West. 2015. Principle 1- maintain diversity and redundancy. Pages 50-79 in R. Biggs, M. Schluter, and M. L. Schoon, editors. Principles for building resilience. Cambridge University Press, Cambridge, UK. http://dx.doi.org/https://doi.org/10.1017/CBO9781316014240.004

Leslie, H. M., X. Basurto, M. Nenadovic, L. Sievanen, K. C. Cavanaugh, J. J. Cota-Nieto, B. E. Erisman, E. Finkbeiner, G. Hinojosa-Arango, M. Moreno-Baez, S. Nagavarapu, S. M. W. Reddy, A. Sanchez-Rodriguez, K. Siegel, J. J. UlibarriaValenzuela, A. H. Weatver, and O. Aburto-Oropeza. 2015. Operationalizing the social-ecological systems framework to assess sustainability. Proceedings of the National Academy of Science 112:5979-5984. http://dx.doi.org/10.1073/pnas.1414640112

Leslie, P., and T. McCabe. 2013. Response diversity and resilience in social-ecological systems. Current Anthropology 54(2):114143. http://dx.doi.org/10.1086/669563

Liu, J., T. Dietz, S. Carpenter, M. Alberti, C. Folke, E. Moran, A. N. Pell, P. Deadman, T. Kratz, J. Lubchenco, E. Ostrom, Z. Ouyang, W. Provencher, C. L. Redman, S. H. Schneider, and W. W. Taylor. 2007a. Complexity of coupled human and natural systems. Science 317:1513-1516. http://dx.doi.org/https://doi. org/10.1126/science.1144004

Liu, J., T. Dietz, S. Carpenter, C. Folke, M. Alberti, and C. L. Reddy. 2007b. Coupled human and natural systems. Ambio 36 (8):639-649. http://dx.doi.org/https://doi.org/10.1579/0044-7447 (2007)36[639:CHANS]2.0.CO;2

Low, B., E. Ostrom, C. Simon, and J. Wilson. 2003. Redundancy and diversity: do they influence optimal management. Pages 83 114 in F. Berkes, J. Colding, and C. Folke, editors. Navigating social-ecological systems: building resilience for complexity and change. Cambridge University Press, Cambridge, UK. http://dx. doi.org/10.1017/cbo9780511541957.007 
McConnell, W. J., J. D. A. Millington, N. J. Reo, M. Alberti, H. Asbjornsen, L. A. Baker, N. Brozovic, L. E. Drinkwater, S. A. Drzyzga, J. Fragoso, D. S. Holland, C. A. Jantz, T. A. Kohler, H. D. G. Maschner, M. Monticino, G. Podesta, R. G. Pontius, Jr., C. L. Redman, D. Sailer, G. Urquhart, and J. Liu. 2011. Research on coupled human and natural systems (CHAINS): approach, challenges, and strategies. U.S. Regional Association of the International Association for Landscape Ecology. Bulletin of the Ecological Society of America, Snowbird, Utah, USA.

Meadows, D. 1999. Leverage points: places to intervene in a system. The Sustainability Institute, Hartland, Vermont, USA.

Merschel, A. G., T. Spies, and E. K. Heyerdahl. 2014. Mixed conifer forests of central Oregon: effects of logging and fire exclusion vary with environment. Ecological Applications 24:1670-1866. http://dx.doi.org/10.1890/13-1585.1

Mori, A., T. Furukawa, and T. Sasaki. 2013. Response diversity determines the resilience of ecosystems to environmental change. Biological Reviews 88:349-364. http://dx.doi.org/10.1111/ brv. 12004

Moritz, M. A., E. Batllori, R. A. Bradstock, A. M. Gill, J. Handmer, P. F. Hessburg, J. Leonard, S. McCaffrey, D. C. Odion, T. Schoennagel, and A. D. Syphard. 2014. Learning to coexist with wildfire. Nature 515:58-66. http://dx.doi.org/10.1038/ nature13946

Nielsen-Pincus, M., S. Charnley, and C. Moseley. 2013. The influence of market proximity on national forest hazardous fuels treatment. Forest Science 59(5): 566-577. http://dx.doi. org/10.5849/forsci.11-096

Norberg, J., and G. S. Cumming. 2008. Complexity theory for a sustainable future. Columbia University Press, New York, New York, USA.

Norberg, J., J. Wilson, B. Walker, and E. Ostrom. 2008. Diversity and resilience of social-ecological systems. Pages 48-80 in J. Norberg and G. S. Cumming, editors. Complexity theory for a sustainable future. Columbia University Press. New York, New York, USA.

North, M. P., S. L. Stephens, B. M. Collins, J. K. Agee, G. Aplet, J. F. Franklin, and P. Z. Fulé. 2015. Reform forest fire management: Agency incentives undermine policy effectiveness. Science 349(6254):1280-1281. http://dx.doi.org/10.1126/science. $\underline{\text { aab2356 }}$

Ohmann, J. L., M. J. Gregory, E. B. Henderson, and H. M. Roberts. 2011. Mapping gradients of community composition with nearest-neighbour imputation: extending plot data for landscape analysis. Journal of Vegetation Science 22(4):660-676. http://dx.doi.org/10.1111/j.1654-1103.2010.01244.x

Oregon Forest Resources Institute. 2010. Federal forestland in Oregon. Oregon Forest Resources Institute, Portland, Oregon, USA. [online] URL: http://oregonforests.org/sites/default/files/ publications/pdf/Federal Forestlands.pdf

Raymond, C. L., and D. L. Peterson. 2005. Fuel treatments alter the effects of wildfire in a mixed-evergreen forest, Oregon, USA. Canadian Journal of Forest Research 35(12):2981-2995. http://dx. doi.org/10.1139/x05-206
Rollins, M. G. 2009. LANDFIRE: a nationally consistent vegetation, wildland fire, and fuel assessment. International Journal of Wildland Fire 18:235-249. http://dx.doi.org/10.1071/ WF08088

Rounesvell, M. D. A., D. T. Robinson, and D. Murray-Rust. 2012. From actors to agents in socio-ecological systems models. Philosophical Transactions of the Royal Society B: Biological Sciences 367(1586):259-269. http://dx.doi.org/10.1098/rstb.2011.0187

Scott, J. H., and R. E. Burgan. 2005. Standard fire behavior fuel models: a comprehensive set for use with Rothermel's surface fire spread model. U.S. Forest Service General Technical Report RMRS-GTR-153.

Spies, T. A. K. N. Johnson, K. M. Burnett, J. L. Ohmann, B. C. McComb, G. H. Reeves, P. Bettinger, J. D. Kline, and B. GarberYonts. 2007. Cumulative ecological and socioeconomic effects of forest policies in coastal Oregon. Ecological Applications 17(1):517. http://dx.doi.org/10.1890/1051-0761(2007)017[0005:ceaseo] 2.0.co; 2

Spies, T. A., E. White, A. Ager, J. D. Kline, J. P. Bolte, E. K. Platt, K. A. Olsen, R. J. Pabst, A. M.G. Barros, J. D. Bailey, S. Charnley, J. Koch, M. M. Steen-Adams, P. H. Singleton, J. Sulzman, C. Schwartz, and B. Csuti. 2017. Using an agent-based model to examine forest management outcomes in a fire-prone landscape in Oregon, USA. Ecology and Society 22(1):25. https://doi. org/10.5751/ES-08841-220125

Spies, T. A., E. M. White, J. D. Kline, A. P. Fischer, A. Ager, J. Bailey, J. Bolte, J. Koch, E. Platt, C. S. Olsen, D. Jacobs, B. Schindler, M. Steen-Adams, and R. Hammer. 2014. Examining fire-prone forest landscapes as coupled human and natural systems. Ecology and Society 19(3):9. http://dx.doi.org/10.5751/ es-06584-190309

Stanfield, B. J., J. C. Bliss, and T. A. Spies. 2002. Land ownerships and landscape structure: a spatial analysis of sixty-six Oregon (USA) Coast Range watersheds. Landscape Ecology 17:685-697. http://dx.doi.org/10.1023/A:1022977614403

Steen-Adams. M., N. Langston, M. D. O. Adams, and D. J. Mladenoff. 2015. Historical framework to explain long-term coupled human and natural system feedbacks: application to a multiple-ownership forest landscape in the northern Great Lakes region, USA. Ecology and Society 20(1):28. http://dx.doi. org/10.5751/es-06930-200128

Stephens, S. L., J. D. McIver, R. E. Boerner, C. Fettig, J. B. Fontaine, B. R. Hartsough, P. L. Kennedy, and D. W. Schwilk. 2012. The effects of forest fuel-reduction treatments in the United States. BioScience 62(6):549-560. http://dx.doi.org/https://doi. org/10.1525/bio.2012.62.6.6

Stine, P., P. Hessburg, T. Spies, M. Kramer, C. J. Fettig, A. Hansen, J. Lehmkuhl, K. O'Hara, K. Polivka, P. Singleton, and S. Charnley. 2014. The ecology and management of moist mixedconifer forests in eastern Oregon and Washington: a synthesis of the relevant biophysical science and implications for future land management. U.S. Forest Service General Technical Report PNWGTR-897. http://dx.doi.org/10.2737/pnw-gtr-897

Swan, L., J. Tokarczyk, and B. Kaetzel. 2013. Eastern Oregon primary wood products processing facilities and operations, 
November, 2012 (Revised May, 2013). U.S. Forest Service, State and Private Forestry, Region 5, Vallejo, California, USA.

Turner, M. G., D. N. Wear, and R. O. Flamm. 1996. Land ownership and land-cover change in the southern Appalachian highlights and the Olympic Peninsula. Ecological Applications 6 (4):1150-1172. http://dx.doi.org/https://doi.org/10.2307/2269599

Walker, B., L. Gunderson, A. Kinzig, C. Folke, S. Carpenter, and L. Schultz. 2006. A handful of heuristics and some propositions for understanding resilience in social-ecological systems. Ecology and Society 11(1):13. http://dx.doi.org/10.5751/es-01530-110113 


\section{Appendix 1}

Effect of fire severity and management actions on forest structure and fuel models

Table A1.1. Effect of fire severity and management on average tree size, canopy cover, layering, and fuels in state-transition vegetation classes. $\mathrm{QMD}=$ quadratic mean diameter.

\begin{tabular}{|c|c|c|c|c|}
\hline \multirow{2}{*}{$\begin{array}{c}\text { Fire severity / } \\
\text { management activity }\end{array}$} & \multicolumn{4}{|c|}{ Effect of disturbance / management activity } \\
\hline & Size (QMD) & Canopy cover & Number of canopy layers & Fuels \\
\hline $\begin{array}{l}\text { Surface fire (includes } \\
\text { prescribed fire) }\end{array}$ & No change & No change & $\begin{array}{l}\text { Reduces multi-layered } \\
\text { states to single layer for } \\
\text { some vegetation states }\end{array}$ & $\begin{array}{l}\text { Reduces surface fuels; } \\
\text { transitions to fuel model } \\
181 \text { or } 182 \text { (low load } \\
\text { compact litter) }\end{array}$ \\
\hline Mixed-severity fire & No change & $\begin{array}{c}\text { Decreases cover by } \\
\text { one or two classes } \\
\text { (e.g., high to } \\
\text { moderate, moderate } \\
\text { to low, moderate to } \\
\text { open) }\end{array}$ & $\begin{array}{l}\text { Reduces multi-layered } \\
\text { states to single layer }\end{array}$ & $\begin{array}{l}\text { Reduces surface fuels; } \\
\text { post-fire fuel model } \\
\text { depends on pre-fire state }\end{array}$ \\
\hline Stand-replacing fire & $\begin{array}{l}\text { Trees are killed; } \\
\text { transition to grass- } \\
\text { forb or shrub } \\
\text { vegetation state }\end{array}$ & $\begin{array}{l}\text { Decreases tree cover } \\
\text { to none or low }\end{array}$ & No canopy layers remain & $\begin{array}{l}\text { Reduces surface fuels; } \\
\text { transition to fuel model } \\
181 \text { (low load compact } \\
\text { conifer litter) }\end{array}$ \\
\hline Mowing and grinding & No change & No change & No change & $\begin{array}{l}\text { Eliminates shrub layers } \\
\text { and increases surface } \\
\text { fuel; transition to } \\
\text { custom model for } \\
\text { masticated fuel beds }\end{array}$ \\
\hline
\end{tabular}


Pre-commercial thinning

No change

Thin from below

No change

Partial harvest

Partial harvest - heavy

Reduces size by one class (e.g., large to medium)

Primarily no change cover by one class in high and moderate cover states

Decreases cover by one or two classes

(e.g., high to

moderate, moderate

to low, moderate to open)

Trees are removed;

Regeneration harvest transitions to grassforb or shrub state

Decreases tree cover to none or low

No canopy layers remain

Reduces multi-layered states to single layer

Generally reduces multilayered states to single

layer

tates to single

layer

Increases surface fuels; transitions to fuel model 185 (high load conifer litter)

Increases surface fuels; transitions to fuel model 185 (high load conifer litter)

Increases surface fuels; transitions to fuel model 185 (high load conifer litter)

Increases surface fuels; transitions to fuel model 185 (high load conifer litter)

Increases surface fuels; transitions to fuel model 185 (high load conifer litter)

Increases surface fuels; transitions to fuel model 185 (high load conifer
Post-fire salvage of dead trees
No effect
No effect litter) 


\section{Appendix 2}

Historical context for forest management, southcentral Oregon

\section{National Forest Management}

The Fremont-Winema National Forest (FWNF) is comprised of two national forests that administratively combined in 2002 - the Fremont National Forest to the east and the Winema National Forest to the west. The Winema side is 445,154 ha in size and located in Klamath County. It lies primarily on the eastern slopes of the Cascade Mountain Range and stretches east into the Klamath River Basin. It is ninety percent tree covered, and is dominated by ponderosa and lodgepole pine and mixed conifer forests. The Fremont side is drier, dominated by sagebrush in the basins, juniper on the hillslopes, and mixed conifer and ponderosa pine forests in the mountainous areas. The Fremont side is located in Lake County and encompasses 485,623 ha (FWNF website).

The two sides of the FWNF have different management histories. The Fremont National Forest was established in 1908; the Winema National Forest in 1961. The Fremont side contains the 199,365 ha Lakeview Federal Sustained Yield Unit (representing about forty percent of its total acreage), created in 1950 with the goal of producing sustainable timber harvests to economically benefit local communities and sustain local mills (Cheek 1996). This unit was reauthorized in 2001 as the Lakeview Stewardship Unit, whose purpose was to integrate ecological, social, and economic sustainability in the context of active management to achieve ecosystem restoration (Lakeview Stewardship Group 2011). The unit must meet annual volume targets for timber production. Management occurs in close collaboration with the long-standing Lakeview Stewardship Group.

In contrast, over half of the Winema National Forest was once part of the Klamath Indian Reservation (FWNF website). Congress terminated federal recognition for the Klamath Tribes under the Klamath Termination Act of 1954, taking much of their reservation land and putting it into the Winema National Forest (The Klamath Tribes website). The rest of the Winema was created from parts of other national forests in the Cascade Range, together with new land acquisitions (FWNF website). Current management takes place in consultation with the Klamath Tribes, who retain fishing, hunting, trapping, and gathering rights, and have developed a forest management plan for their former reservation lands.

\section{State Forest Management}

Management of the Sun Pass and Gilchrist State Forests occurs under the same management plan (ODF 1995), but forest management differs on the two forests owing to their different histories. Most of what is now the 8,419 ha Sun Pass State Forest was purchased by the State of Oregon in the 1940s and was formerly private industrial timberland (ODF 1995). Because much of the high value timber had been cut by the previous owners, only light management occurred until the 1990s so that the forest could develop. The State of Oregon purchased the 17,401 ha Gilchrist State Forest in 2010 in order to protect open space, public access, and working forestlands, and 
prevent their subdivision for real estate development (ODF Gilchrist State Forest, interview data). These lands were owned by the local, family-owned Gilchrist Timber Company for most of the $20^{\text {th }}$ century, and then sold to Crown Pacific in 1991. Crown Pacific was a private industrial timber company that liquidated the timber on these forestlands in the 1990s to pay off its debts (ODF Gilchrist State Forest). It then went bankrupt, and the lands were acquired by another private corporate owner in 2005 that engages in real estate investment and development. ODF purchased the land from this owner. An adjacent 10,453 ha block, sharing this same history, was simultaneously purchased by The Conservation Fund (a non-profit organization) in 2010, and held until the State could acquire it and add it to the Gilchrist State Forest, which occurred in 2015. Both tracts have been managed by ODF since 2010, and are collectively referred to here as the Gilchrist State Forest. The dominant forest type is ponderosa pine, but trees average only 20 years old because of this harvest history (ODF Gilchrist State Forest).

\section{Private Corporate Forest Management}

The five private corporate owners in the study area own lands having different management histories. Two are relatively small, family-owned private industrial timber companies that have been operating in the region since the 1930s-1940s, gradually acquiring new parcels over time by purchasing them from other private industrial timber companies that once operated in the area. Their forestlands have been certified to Forest Stewardship Council standards for socially and ecologically responsible forest management. One private corporate owner was created in 2006 by a local family upon purchasing about 250,905 ha of timberlands in central and southcentral Oregon from a timber investment management organization. That organization bought them in 1996 from a private industrial timber company that had owned timberlands in the region since the early 1900s. A fourth owner is a real estate investment company that invests in agricultural, timber, and mining property throughout the US to produce income and realize the long-term appreciation potential of the land. This company acquired its forestland in the study area at auction in 2011 from a private owner. These forestlands were only lightly harvested by the preceding owner until the national economic recession began in 2008. The fifth private corporate owner was created in 2004 as a subsidiary of a larger company that engages in real estate investment and development. It then acquired forestlands from a private industrial forestry company after it went bankrupt. These lands were heavily harvested by the former owner. One large tract of this ownership was formerly part of the Klamath Tribal Reservation lands. Although this tract transferred to private ownership in 1960, the Forest Service has since been responsible for overseeing management there under its own management plan, revised every ten years. Since 2005 and during the time of our study, this ownership was for sale for real estate development. Two of the five private corporate ownerships were sold and changed hands following our fieldwork.

\section{Literature Cited}

Cheek, K. 1996. Community Well-Being and Forest Service Policy: Re-Examining the Sustained Yield Unit. MA Thesis, Department of Forest Resources, Oregon State University, Corvallis, OR. 
Fremont-Winema National Forest (FWNF). Fremont-Winema National Forests History [Online]. Available: http://www.fs.usda.gov/detail/fremont-winema/about-forest/?cid=fsbdev3_061912 [Accessed November 5, 2015].

Lakeview Stewardship Group. 2011. Long range strategy for the Lakeview Federal Sustained Yield Unit. http://www.fs.usda.gov/Internet/FSE_DOCUMENTS/stelprdb5356799.pdf

[Accessed July 11, 2016].

Oregon Department of Forestry (ODF). Gilchrist State Forest [Online]. Available: http://www.oregon.gov/ODF/Working/Pages/StateForests.aspx [Accessed September 29, 2015].

Oregon Department of Forestry (ODF). 1995. Eastern Region Long-Range Management Plan [Online].

Available: http://www.oregon.gov/ODF/Documents/AboutODF/FMPEasternOregon1995.pdf [Accessed October 3, 2015].

The Klamath Tribes, Klamath Tribes history [Online]. Available: http://www.klamathtribes.org/history/ [Accessed July 11, 2016]. 